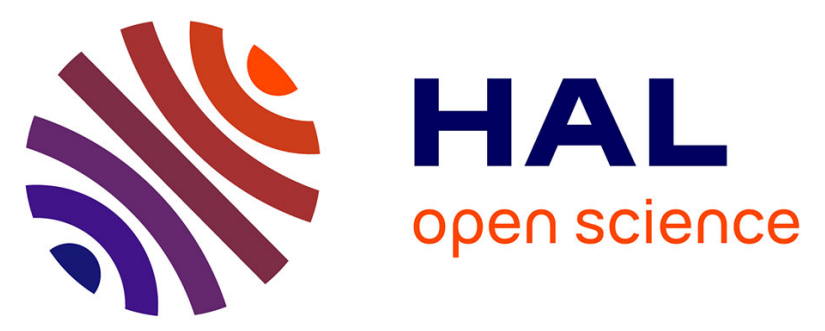

\title{
Ordered mesoporous Fe-Al2O3 based-catalysts synthesized via a direct "one-pot" method for the dry reforming of a model biogas mixture
}

Karam Jabbour, Ali Saad, Lena Inaty, Anne Davidson, Pascale Massiani, Nissrine El Hassan

\section{To cite this version:}

Karam Jabbour, Ali Saad, Lena Inaty, Anne Davidson, Pascale Massiani, et al.. Ordered mesoporous Fe-Al2O3 based-catalysts synthesized via a direct "one-pot" method for the dry reforming of a model biogas mixture. International Journal of Hydrogen Energy, 2019, 44 (29), pp.14889-14907. 10.1016/j.ijhydene.2019.04.110 . hal-02414764

\author{
HAL Id: hal-02414764 \\ https://hal.science/hal-02414764
}

Submitted on 15 Dec 2020

HAL is a multi-disciplinary open access archive for the deposit and dissemination of scientific research documents, whether they are published or not. The documents may come from teaching and research institutions in France or abroad, or from public or private research centers.
L'archive ouverte pluridisciplinaire HAL, est destinée au dépôt et à la diffusion de documents scientifiques de niveau recherche, publiés ou non, émanant des établissements d'enseignement et de recherche français ou étrangers, des laboratoires publics ou privés. 


\section{Ordered mesoporous $\mathrm{Fe}-\mathrm{Al}_{2} \mathrm{O}_{3}$ based-catalysts synthesized via a direct "one- pot" method for the dry reforming of a model biogas mixture}

Karam Jabbour ${ }^{a,},{ }^{,}$Ali Saad $^{a}$, Lena Inaty ${ }^{a}$, Anne Davidson $^{b}$, Pascale Massiani ${ }^{b, c}$, Nissrine El Hassan $^{a, * *}$

a Department of Chemical Engineering, Faculty of Engineering, University of Balamand, P.O. Box 100, Tripoli, Lebanon

b Sorbonne Universités, UPMC Université Paris 06, Laboratoire de Réactivité de Surface, 4 place Jussieu, 75005 Paris, France

c CNRS UMR 7197, UPMC, Laboratoire de Réactivité de Surface, 4 place Jussieu, 75005 Paris, France

\section{Abstract}

Biogas plays a vital role in the emerging renewable energy sector and its efficient utilization is attracting significant attention as an alternative energy carrier to non-renewable fossil fuel resources. Since biogas consists mainly of $\mathrm{CH}_{4}$ and $\mathrm{CO}_{2}$, dry reforming of methane arises as an appropriate process enabling its chemical conversion to high-quality synthesis gas (syngas: $\mathrm{H}_{2}$ and $\mathrm{CO}$ mixtures). In this study, we synthesized via a direct "one-pot" method following an evaporation-induced self-assembly approach, ordered mesoporous $\mathrm{Fe}_{10 \%}, \mathrm{Ni}_{5 \%}$ and $\mathrm{Fe}_{\mathrm{x} \%} \mathrm{Ni}_{(1-\mathrm{x})}$ (x: 2.5, 5 or $7.5 \%$ ) in $\mathrm{Al}_{2} \mathrm{O}_{3}$ as catalysts for syngas production via dry reforming of a model biogas mixture $\left(\mathrm{CH}_{4} / \mathrm{CO}_{2} 1 / 41.8\right.$, at a temperature of $\left.700 \circ \mathrm{C}\right)$. Monometallic $\mathrm{Fe}_{10 \%} \mathrm{Al}_{2} \mathrm{O}_{3}$ catalyst presented lower reactivity levels and slightly deactivated during catalysis compared to stable $\mathrm{Ni}_{5 \%} \mathrm{Al}_{2} \mathrm{O}_{3}$. According to physico-chemical characterization techniques, the incomplete reduction of $\mathrm{Fe}_{2} \mathrm{O}_{3}$ into $\mathrm{Fe}_{3} \mathrm{O}_{4}$ rather than $\mathrm{Fe}^{0}$ nanoparticles (catalytically active) coupled with the segregation of $\mathrm{Fe}_{3} \mathrm{O}_{4}$ oxides were the main factors leading to the low performance of mesoporous $\mathrm{Fe}_{10 \%} \mathrm{Al}_{2} \mathrm{O}_{3}$. These drawbacks were overcome upon the partial substitution of $\mathrm{Fe}$ by $\mathrm{Ni}$ (another transition metal) forming specifically bimetallic $\mathrm{Fe}_{5 \%} \mathrm{Ni}_{5 \%} \mathrm{Al}_{2} \mathrm{O}_{3}$ displaying reactivity levels close to thermodynamic expected ones. The formation of Fe-Ni alloys stabilized iron inside alumina matrix and protected it from segregation. Along with the confinement effect, spent catalyst characterizations showed high resistance towards coke deposition.

\section{Introduction}

The decline in non-renewable fossil fuel energy reserves and associated environmental regulations regarding uncontrolled $\mathrm{CO}_{2}$ emissions stress on the consideration of sustainable alternatives for energy production purposes. Biogas, produced from the anaerobic digestion of organic waste, is a gaseous mixture of $\mathrm{CH}_{4}$ (50e70 vol\%), $\mathrm{CO}_{2}$ (30e50 vol\%) along with small amounts of impurities such as $\mathrm{NH}_{3}, \mathrm{H}_{2} \mathrm{~S}$, organic sulphur and water vapour, that is recently gaining significant industrial attention as a renewable source of carbon $[1,2]$. Conventionally, after purification, biogas can be directly combusted for heat and electricity generation yet, the heat value of such combustion processes is low due to the high 
concentration of $\mathrm{CO}_{2}$ in the feed gas [3]. From an efficiency point of view, biogas can be either converted into synthesis gas (syngas, $\mathrm{H}_{2}$ and $\mathrm{CO}$ mixtures) for versatile industrial applications. Depending on the molar $\mathrm{H}_{2}: \mathrm{CO}$ ratio in the reformed bio-syngas, it can be directly applied as a feedstock for the production of methanol, dimethyl ether (DME), long hydrocarbon chains via Fischer-Tropsch (FT) process [4] or $\mathrm{NH}_{3}$ synthesis by the Haber route [5]. Steam reforming of methane (SRM) produces a hydrogen- rich synthesis gas $\left(\mathrm{H}_{2}: \mathrm{CO} 1 / 4\right.$ 3:1), suitable for downstream ap- plications such as $\mathrm{NH}_{3}$ production. In contrast, dry reforming of methane (DRM), where $\mathrm{CO}_{2}$ re- places water, generates a syngas with an equimolar content of $\mathrm{H}_{2}$ to $\mathrm{CO}\left(\mathrm{H}_{2}: \mathrm{CO} \frac{1}{4} 1\right)$ appropriate for FT process. Combining the two processes allows tuning syngas combinations with $\mathrm{H}_{2}$ : $\mathrm{CO}$ molar ratios ranging from 1 till 3 , which becomes important for methanol and DME syntheses $[6,7]$.

As recently reviewed by Kawi et al. [8], reforming reactions involving $\mathrm{CO}_{2}$ as a main reagent (notably DRM) are regarded as a basis for research studies aiming to upgrade the calorific value of hydrocarbons for most of the procedures centered around reforming of natural gas. Adding to these energetic advantages, dry reforming appears as the most suitable path for biogas transformation into bio-syngas because of its composition (mainly $\mathrm{CH}_{4}$ and $\mathrm{CO}_{2}$ ) that makes it an interesting feedstock for this process [9]. Therefore, the production of syngas mixtures from renewable energy resources, typically biogas, is a favorable route in order to decrease the emissions of carbon dioxide [10]. $\mathrm{CO}_{2}$ gas, the most problematic green- house gas, will be consumed by the reforming reaction instead of being released to the atmosphere [11] thus, curbing the global climate change issue and providing an avenue for exploring technologies contributing to carbon cycles establishments [12].

Typically, the design of a biogas dry reforming catalyst (inlet ratio of $\mathrm{CH}_{4} / \mathrm{CO}_{2}$ greater than 1) should be based on all of the reported tactics that constitute low cost, selective and stable DRM (inlet ratio of $\mathrm{CH}_{4} / \mathrm{CO}_{2} 1 / 4$ 1) catalysts with an added focus on the deactivation modes that could result from excess $\mathrm{CH}_{4}$ in the gas feed. Along with the main biogas reforming reaction, secondary reactions such as the reverse-water gas- shift (RWGS), methane decomposition (MD) and Boudouard reaction (BR) could amend the overall performance of the catalyst. Actually, selectivity towards an equimolar product ratiois altered by the RWGS due to the production of excess $\mathrm{CO}$ leading to a decrease in the $\mathrm{H}_{2}$ : $\mathrm{CO}$ ratio in the product steam. Another important problem encountered in the course of biogas dry reforming is coke formation through MD and/or BR where; the former is most pronounced at high reaction temperatures (close to those required for the main DRM) whereas the latter generally occurs at lower temperatures. The development of solid $\mathrm{C}_{(\mathrm{s})}$ carbonaceous deposits on the inner and/or outer catalytic surfaces contribute in catalyst deactivation and plugging of the reactor [13]. Besides, due to the high endo- thermic character of the reforming reaction, sintering (or agglomeration) of nanoparticles and loss of active surface area is an additional drawback towards the industrialization of the dry reforming process [14]. 
As for typical DRM catalysts, supported catalysts contain- ing noble metals such as Ru and $\mathrm{Rh}$ are active catalysts in biogas reforming reaching high $\mathrm{CH}_{4}$ and $\mathrm{CO}_{2}$ conversions with a stable reactivity on stream even at temperatures exceeding 640 o $C[8,15,16]$. However, their substitution by non-noble (i.e. $\mathrm{Ni}$, Fe or $\mathrm{Co}$ ) metals $[9,17]$ is nowadays a popular approach from both environmental and economical perspectives. Despite their potential deactivation on stream (due to coke deposition and/or nanoparticles agglomeration), $\mathrm{Ni}$ based catalysts remain the most preferred choice among the non- noble family of metals due to their good intrinsic activity levels being comparable to those of noble metals $[18,19]$.

To increase catalytic performance and decrease carbon deposition and sintering effects on $\mathrm{Ni}$-based catalysts in the course of biogas dry reforming; several parameters have been lately studied such as: addition of promoters [9,20e23], sup- port type [24] and, alteration of synthesis techniques [10,25]. For instance, Moura-Nickel at al [21]. developed effective $\mathrm{Ni}-\mathrm{Y}_{2} \mathrm{O}_{3}-\mathrm{Al}_{2} \mathrm{O}_{3}$ catalysts for biogas dry reforming and reported performances significantly higher than those obtained on unprompted $\mathrm{Ni}-\mathrm{Al}_{2} \mathrm{O}_{3}$ catalyst. The high activity was attributed to a decrease in coke formation in presence of yttrium oxide by promoting a higher degree of interaction between $\mathrm{Ni}$ and the alumina matrix. Similarly, Charisiou et al. [22] ascribed the enhanced performance of their $\mathrm{CeO}_{2}$ or $\mathrm{La}_{2} \mathrm{O}_{3}$ promoted $\mathrm{Ni} / \mathrm{Al}_{2} \mathrm{O}_{3}$ to a higher dispersion of nickel nanoparticles resulting in an enhanced metal-support interaction and thus, a higher resistance to carbon formation upon facilitating the activation of $\mathrm{CO}_{2}$ to gasify $\mathrm{C}_{(\mathrm{s})}$ deposits [26e29]. Besides alumina, mixed $\mathrm{TiO}_{2}-\mathrm{Al}_{2} \mathrm{O}_{3}$ likematerials decomposing into mixed oxides stand out as promising supports for $\mathrm{Ni}$ species with high activity and selectivity as compared to $\mathrm{Ni}$ impregnated on pure $\mathrm{Al}_{2} \mathrm{O}_{3}$ [24]. In addition to the incorporation of promoters with specific properties, some of the newest strategies for the development of stable biogas reforming catalysts involve the application of "original" synthesis approaches, such as equilibrium deposition filtration EDF, compared to traditional post-impregnation ones (wet and incipient wetness impregnations) [25]. It was shown that upon depositing $\mathrm{Ni}$ via the EDF method; an improved overall dispersion was achieved reflecting positively on reactivity and selectivity levels for inlet $\mathrm{CH}_{4} / \mathrm{CO}_{2}$ feed stream of 1.5 (molar composition).

Another promising approach is the confinement of well- dispersed nanoparticles within standard oxides having ordered channels for encapsulation reasons, such as porous silica [30e34] or alumina [35e39]. Such porous frameworks can not only exert a spatial restriction on $\mathrm{Ni}^{0}$ species to hamper their sintering and coke formation but also offer a high surface area for the dispersion of these nanoparticles. Accordingly, we have developed catalytic systems based on $\mathrm{Ni}$ impregnated on natural macroporous diatomite silica [40] and synthesized mesoporous SBA-15 [30,31,33] as catalysts for DRM. Better performances were measured for $\mathrm{Ni} / \mathrm{SBA}-15$ compared to $\mathrm{Ni} /$ diatomite due to 1 ) an enhanced dispersion of $\mathrm{Ni}^{0}$ nanoparticles over the mesoporous support and 2) an improved 
confinement effect of $\mathrm{Ni}^{0}$ active phases within the well-ordered mesoporous arrangement of SBA-15. However, metal particles supported in silica-based channels could still migrate from the mesopores to the external surface at high temperatures due to weak metal-support interaction (MSI) where; sintering of nanoparticles is inevitable in these silica- based catalysts. On the contrary, ordered mesoporous alumina was shown to have a greater tendency to interact with metal particles. Nanoparticles are anchored in their frameworks with strong MSI resulting in prominent anti- sintering property especially when the catalyst is prepared following active phase introduction directly during the syn- thesis ("onepot" synthesis allowing solid solution formation). Indeed, we recently designed a mesoporous $\mathrm{Ni}$-containing alumina catalyst by adopting the "one-pot" technique following an evaporation-induced self-assembly (EISA) method in presence of a structuring agent $[41,42]$. The "one- pot" catalyst, with nickel nanoparticles highly dispersed and stabilized inside the $\mathrm{Al}_{2} \mathrm{O}_{3}$ matrix was found significantly more active and stable in combined methane reforming than impregnated catalysts [43].

More recently, testing the reactivity of transition, non $\mathrm{Ni}$ - based, metals specifically iron is becoming desirable due to its high availability and extremely low price that is approximately 250 times lower than that of $\mathrm{Ni}$ or $\mathrm{Co}[44,45]$. The utilization of $\mathrm{Fe}$ dispersed on either $\mathrm{ZrO}_{2}$ [46], $\mathrm{MgAl}_{2} \mathrm{O}_{4}$ [47] or $\mathrm{Al}_{2} \mathrm{O}_{3}$ [48,49] oxides have been reported for methanation re- actions and exhibited promising performances. Moreover, Fe- based catalysts have been also studied for standard methane dry reforming (equimolar inlet feed) [50], reforming of ethylene [51], CO methanation [52] and, $\mathrm{CO}_{2}$ hydrogenation [53]. The catalytic data over Fe containing catalysts were encouraging. The usage of Fe in the reforming of model biogas mixtures in still scarcely reported in literature despite their highly attractive economical advantage. Nevertheless, monometallic Fe catalysts deactivate on stream and deactivation reasons are vaguely discussed in literature. Reported data scarcely address the parameters leading to the deactivation of iron but promotes enhancement strategies that lie on coupling Fe to either noble ( $\mathrm{Ru}$ ) [49] or non-noble (mainly $\mathrm{Ni}$ ) [46e48,50,51] metals in bimetallic catalytic systems. It is worth mentioning that all of the reported tactics involving bimetallic catalysts deal with the probable promotional effect of Fe on the other metal whereas, focusing on the enhancement of the reactivity of Fe by the secondary metal could be of great interest for the development of low-cost iron-based materials (predominately composed of Fe) for industrial applications.

Based on this state of the art, the present work aimed at developing "one-pot" synthesized ordered mesoporous $\mathrm{Fe}$ in $\mathrm{Al}_{2} \mathrm{O}_{3}$ catalysts for testing in dry reforming of a model biogas $\left(\mathrm{CH}_{4} / \mathrm{CO}_{2} \quad 1 / 4 \quad 1.8\right)$ in order to obtain an understanding on the reactivity of $\mathrm{Fe}$ towards syngas production upon emphasizing on the factors that affect reactivity and selectivity levels. Despite the particular properties of orderedstructured materials and the expectation of promising performances even under 
biogas dry reforming conditions [21], studies dealing with the direct preparation of such oxides housing nanoparticles in their porous walls for their application in the dry reforming of model biogas mixtures is still very limited. In addition, there exists to our knowledge no work establishing correlation between the catalytic performances, the physicochemical properties and, deactivation behaviors of "onepot" synthesized iron in alumina under harsh biogas reforming conditions (T 1/4 700 ${ }^{\circ} \mathrm{C}$, excess $\mathrm{CH}_{4}$ in inlet feed potentially results in heavy $\mathrm{C}_{(\mathrm{s})}$ deposition). For the sake of completion, low cost $\mathrm{Ni}^{2 \mathrm{~b}}$ salts were also introduced, based on their high reactivity levels in methane reforming reactions $[16,17,49,50]$, in the design of "one-pot" bimetallic $\mathrm{Fe}-\mathrm{Ni}-\mathrm{Al}_{2} \mathrm{O}_{3}$ catalysts upon varying $\mathrm{Fe}$ :Ni molar content (range from 0.33 till 3). The "one-pot" synthesis method along with metal contents were chosen based on recent works [29e33,43] displaying catalysts with promising performances for dry (inlet $\mathrm{CH}_{4} / \mathrm{CO}_{2} \quad \frac{1}{4} \quad 1$ ) and combined dry and steam (inlet $\mathrm{CH}_{4} / \mathrm{H}_{2} \mathrm{O} / \mathrm{CO}_{2} 1 / 4$ 1/0.8/0.4) reforming reactions.

\section{Experimental procedures}

\section{Preparation of mesoporous "one-pot" alumina based-materials}

Monometallic mesoporous $\mathrm{Fe}_{10 \%} \mathrm{Al}_{2} \mathrm{O}_{3}$ and $\mathrm{Ni}_{5 \%} \mathrm{Al}_{2} \mathrm{O}_{3}$ (refer- ence material) and bimetallic $\mathrm{Fe}_{\mathrm{x} \%} \mathrm{Ni}_{(1-\mathrm{x}) \%} \mathrm{Al}_{2} \mathrm{O}_{3}$ (y $1 / 42.5,5$ or $7.5 \%$, total metal content fixed at 10 wt\%) samples were synthesized following a well-established "one-pot" EISA method $[41,42]$ with some minor modifications $[29,43]$. Typi- cally, the synthesis consisted in dissolving, at room temper-ature (RT), $1.0 \mathrm{~g}$ of P123 Pluronic triblock copolymer $\left((E O)_{20}(P O)_{70}(E O)_{20}, M_{n} 1 / 45800\right.$, Sigma Aldrich, 43546-5) in $20 \mathrm{ml}$ of absolute ethanol $\left(\mathrm{CH}_{3} \mathrm{CH}_{2} \mathrm{OH}\right.$, Sigma Aldrich, 64-17-5) under vigorous stirring. After complete dissolution of the structuring agent, $1.6 \mathrm{ml}$ nitric acid $\left(65.0 \mathrm{wt} \%\right.$ aqueous $\mathrm{HNO}_{3}$, Johnson Matthey S.A., extra pure) was added, still under stirring, together with $A$ mmol of aluminium isopropoxide $\left(\mathrm{Al}\left(\mathrm{OPr}^{\mathrm{i}}\right)_{3}, \mathrm{C}_{9} \mathrm{H}_{21} \mathrm{AlO}_{3}, 98 \mathrm{p} \%\right.$, Sigma Aldrich, 220418), B mmol of iron (III) nitrate nanohydrate $\left(\mathrm{FeN}_{3} \mathrm{O}_{9} \cdot 9 \mathrm{H}_{2} \mathrm{O}\right.$, Sigma Aldrich, 216828) and/or $\mathrm{C}$ mmol of nickel nitrate hexahydrate $\left(\mathrm{Ni}\left(\mathrm{NO}_{3}\right)_{2} \cdot 6 \mathrm{H}_{2} \mathrm{O}\right.$, Sigma Aldrich, 13478-007). All the chemicals were used as received, without further purification. For each synthesis, the total molar composition was always kept constant, equal to $10 \mathrm{mmol}$ (i.e. [A p B (or C)] $1 / 410 \mathrm{mmol}$ for $\mathrm{Fe}_{10 \%} \mathrm{Al}_{2} \mathrm{O}_{3}$ and $\mathrm{Ni}_{5 \%} \mathrm{Al}_{2} \mathrm{O}_{3}$ samples and [A p B p C] $1 / 410 \mathrm{mmol}$ for $\mathrm{Fe}_{\mathrm{x} \%} \mathrm{Ni}_{(1-\mathrm{x}) \%} \mathrm{Al}_{2} \mathrm{O}_{3}$ ones). This final mixture was covered with a polyethylene (PE) film, continuously stirred at RT for at least $7 \mathrm{~h}$ until complete dissolution, and finally transferred into a double-layer jacketed beaker supplied by a flow of distilled water regulated at $60{ }^{\circ} \mathrm{C}$ to undergo slow evaporation (ethanol, acid) for $48 \mathrm{~h}$ straight. The obtained brown (or greenish) xerogels, which color depending on $\mathrm{Fe}$ (or $\mathrm{Ni}$ ) amount, were slowly calcined in air at $600^{\circ} \mathrm{C}$ for $5 \mathrm{~h}$ (heating rate $0.5^{\circ} \mathrm{C} \mathrm{min}^{-1}$ ) to give calcined "one-pot" aluminabased materials. 


\section{Characterization methods}

Textural properties were determined from $\mathrm{N}_{2}$-sorption (adsorption and desorption) isotherms recorded on an ASAP 2020 Micromeritics apparatus. Prior to measurements, calcined samples were degassed under vacuum for $3 \mathrm{~h}$ at $300{ }^{\circ} \mathrm{C}$ then cooled down to RT before being placed at $-196 \circ \mathrm{C}$ (liquid nitrogen temperature). The Brunauer-Emmett-Teller (BET) surface areas were calculated from the BET equation for a relative pressure $\left(P / P_{0}\right)$ range between 0.05 and 0.25 . The single point pore volume was calculated from the adsorption isotherm at a relative pressure of 0.990 and pore size distri- bution (PSD) was calculated using the Barrett-Joyner- Halenda (BJH) method for the adsorption branch of the isotherm.

Structural characteristics were studied at RT by conducting powder X-ray diffraction (XRD) at wide and small angles. The wide-angle measurements were performed on a PANalytical XPert ${ }^{3}$ diffractometer using $\mathrm{Cu}$ Ka radiation (I $1 / 41.5405 \mathrm{~nm}$ ). The acquisitions were recorded for $2 q$ values between $20.0^{\circ}$ and $90.0^{\circ}$ at a voltage of $30 \mathrm{kV}$, a current of $10 \mathrm{~mA}$ and a step size of $0.04^{\circ}$ (with $2 \mathrm{~s}$ duration at each step). A comparison with standard powder XRD files published by the International Center for Diffraction Data (ICDD) helped in the identification of present crystalline phases. Crystalline domain sizes were estimated using the Scherrer equation. The smallangle data were obtained from 2 theta of $0.5^{\circ}$ to $4.0^{\circ}$ (time per step: $1 \mathrm{~s}$ ) on a BRUKER type D8 ADVANCE diffractometer applying a $\mathrm{Cu}$ Ka irradiation source $(1.5418 \mathrm{~nm})$ and operating at $40 \mathrm{kV}$ and $30 \mathrm{~mA}$. The observed diffraction peaks correspond to families of planes indexed by hkl values (Miller indices) where the distance $d$ separating two parallel plans is calculated according to Brag's law Eq. (1). These data were used to calculate the lattice parameter $(a)$.

The reducibility of iron and nickel species in the prepared (calcined) aluminabased materials was studied by tempera- ture programmed reduction (TPR), carried on an Autochem 2920 (Micromeritics) apparatus equipped with a thermal conductivity detector (TCD) for a constant record of the overall $\mathrm{H}_{2}$ consumption. The powder (100 $\mathrm{mg}$ ) was heated on a quartz wool in a U-shaped quartz sample tube from room tempera- ture to $9000^{\circ} \mathrm{C}$ at a constant rate of $70^{\circ} \mathrm{C} \mathrm{min}^{-1}$ using a gaseous mixture of 5 vol\% $\mathrm{H}_{2} / \mathrm{Ar}\left(30 \mathrm{ml} \mathrm{min}^{-1}\right)$. A cold trap of ice and salt bath $(\mathrm{NaCl})$ was used to condense any water generated during the reduction process before the arrival of the dry gas flow to the TCD detector. This guarantees that the obtained signal (difference in thermal conductivity between reference and analysis gases) is integrally associated with $\mathrm{H}_{2}$ consumption.

The number of surface $\mathrm{Fe}$ and $\mathrm{Ni}$ sites per unit mass of the catalyst (dispersion, $\mathrm{D} \%)$ was determined by means of tem- perature programmed desorption (TPD) using the same apparatus and reactor adopted for TPR experiments. For 
$\mathrm{H}_{2-}$ TPD, $300 \mathrm{mg}$ of calcined powder was first in-situ reduced at $7000^{\circ} \mathrm{C}$ for $2 \mathrm{~h}$ (heating rate of $7{ }^{\circ} \mathrm{C} \mathrm{min}^{-1}$ ) under similar flowing medium as $\mathrm{H}_{2}$-TPR $(5$ vol\%

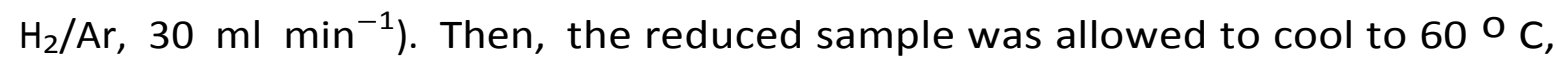
under the same $\mathrm{H}_{2}$-flow, to ensure complete saturation with hydrogen. Physically adsorbed $\mathrm{H}_{2}$ (on the material surface) was flushed by a flow of $\operatorname{Ar}(30 \mathrm{ml}$ $\left.\mathrm{min}^{-1}\right)$ for $2 \mathrm{~h}$ before re-heating the sample, still under $\mathrm{Ar}$, to $900^{\circ} \mathrm{C}\left(10^{\circ} \mathrm{C} \mathrm{min}^{-1}\right)$ for TPD measurements. The volume of desorbed $\mathrm{H}_{2}$ was continuously monitored, as a function of temperature increase, by means of the TCD detector. The dispersion of Fe and $\mathrm{Ni}$ was calculated, based on reported literature [54,55], for an adsorption stoichiometry factor of $\mathrm{H} / \mathrm{Fe}$ (or $\mathrm{Ni}$ ) $1 / 41: 1$, using Eq. (3) below where: $\mathrm{V}_{\mathrm{ad}}(\mathrm{ml})$ represents the volume of desorbed $\mathrm{H}_{2}$ at standard temperature and pressure (STP) conditions measured during TPD procedure, $M$ is (i) for monometallic samples the molecular weight of Fe $\left(55.84 \mathrm{~g} \mathrm{~mol}^{-1}\right)$ or $\mathrm{Ni}(58.69 \mathrm{~g}$ $\mathrm{mol}^{-1}$ ) and (ii) for bimetallic samples it is calculated with respect to the weight percent of $\mathrm{Fe}$ and $\mathrm{Ni}$ used in the preparation, SF is the stoichiometric factor $(\mathrm{H}: \mathrm{Fe}$ (or $\mathrm{Ni}$ ) taken as 1$), \mathrm{m}$ is the sample weight $(0.3 \mathrm{~g}), \mathrm{P}$ is the total weight fraction of $\mathrm{Fe}$ and/or $\mathrm{Ni}$ in the sample (5 or 10\%) and $\mathrm{V}_{\mathrm{m}}$ is the molar volume of $\mathrm{H}_{2}\left(22.414 \mathrm{ml} \mathrm{mol}^{-1}\right)$ at STP.

Scanning electron microscopy (SEM) images were registered on a Hitachi SU-70 SEM-FEG microscope with a $7 \mathrm{kV}$ electron acceleration tension. Transmission electron microscopy (TEM) observations were performed on ultrathin sec- tions of solids to properly visualize the dispersed iron and nickel nanoparticles and their localization inside or outside alumina grains. The preparation of the sections was done as follows: EPON 812 embedding resin was fixed with the powder (few milligrams) and then placed in a beam capsule. The mixture is polymerized at 600 $\mathrm{C}$ for $48 \mathrm{~h}$ straight following the cutting of the blocks into thin slices $(50 \mathrm{e} 70 \mathrm{~nm}$ in thickness). After that, the blocks were deposited on copper grids covered by an inert material (membrane of carbon). TEM images, with main axis cut parallel (longitudinal) or perpendicular (trans- versal) to the electron beam, were recorded on a JEOL-JEM 200 electron microscope operating at $200 \mathrm{keV}$ ( $\mathrm{LaB}_{6}$ gun) and equipped with an energy dispersive spectroscopy (EDS) probe. The "Comptage de Particules" LRS software was used to assess average particle sizes upon considering at least 500 particles for each sample. The obtained values were compared to those estimated from XRD analyses.

Carbon deposition on spent catalysts was quantified using thermal gravimetric analysis (TGA)/differential scanning calorimetry (DSC). TGA/DSC were performed on a TA SDT Q600 thermal analyzer instrument from RT to $9000^{\circ} \mathrm{C}$ (heating rate of $10{ }^{\circ} \mathrm{C} \mathrm{min}^{-1}$ ) in an air flow of $50 \mathrm{ml} \mathrm{min} \mathrm{m}^{-1}$. The qualification of carbonaceous deposits was determined via Raman spectroscopy. Spectra were collected on a KAISER (RXN1) optical system operating at a resolution of $4 \mathrm{~cm}^{-1}, 10$ 
$\mathrm{mW}$ laser intensity, a total of 30 accumulations per spectrum (with 10 s acquisition time). The spectrometer con- sists on a laser with I 1/4 $785 \mathrm{~nm}$, a microscope with an X50 long working distance (W.D. $1 / 48.0 \mathrm{~mm}$ ) lens along with a charge-coupled detector (CCD).

\section{Catalytic measurements}

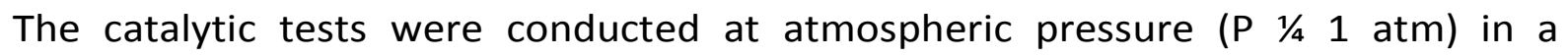
Microactivity Effi (PID Eng and Tech) vertical fixed-bed continuous flow stainless steel (SS310) reactor (9 $\mathrm{mm}$ i.d.). Prior to each reaction, $100 \mathrm{mg}$ of calcined (nondiluted) powder were in-situ reduced at $7000^{\circ} \mathrm{C} / 2 \mathrm{~h}$ under a flow $\left(30 \mathrm{ml} \mathrm{min}{ }^{-1}\right)$ of 5 vol\% $\mathrm{H}_{2} /$ Ar. The choice of reduction temperature was based on the reducibility behavior of the samples deduced from $\mathrm{H}_{2}$-TPR profiles along with the state of $\mathrm{Fe}$ and $\mathrm{Ni}$ species detected from wide-angle XRD patterns. The flow was then switched to the reactant mixture composed of $\mathrm{CH}_{4} / \mathrm{CO}_{2} / \mathrm{Ar} 1 / 41.8 / 1 / 14$, chosen to mimic typical biogas mixtures [20e25,56,57]. Reforming reaction was carried out at 700 ${ }^{\circ} \mathrm{C} / 13 \mathrm{~h}$ for a total gas hourly space velocity (GHSV) of $36 \mathrm{~L} \mathrm{~g}^{-1} \mathrm{hr}^{-1}$. The reaction temperature was controlled using a thermocouple placed in the middle of the catalyst bed. Before analysis (quantification of gas concentrations), the effluent was passed through a gas/liquid separator for condensing water (potentially generated from side-reactions) prior to the arrival of reactant and product flow to the online gas chromatography. The latter Agilent 490 on-line Micro-GC apparatus was equipped with a TCD and two columns placed in parallel for detection of $\mathrm{CH}_{4}, \mathrm{H}_{2}$ and $\mathrm{CO}$ (molecular sieve column) and of $\mathrm{CO}_{2}$ (plot $\mathrm{U}$ column). Reproducibility of the catalytic measurements has been checked. Conversions of $\mathrm{CO}_{2}\left(\mathrm{XCO}_{2}\right), \mathrm{CH}_{4}\left(\mathrm{XCH}_{4}\right)$ and $\mathrm{H}_{2} / \mathrm{CO}$ molar ratio were calculated based on Eqs. (4)e(6): cf published article. And compared to expected thermodynamic ones under the applied reaction conditions (molar ratio of reactants, diluent, temperature and pressure), using the HSC 7.1 Chemistry software (where $\mathrm{H}, \mathrm{S}$, and C stand for the enthalpy, entropy and heat capacity, respectively).

\section{Results and Discussion}

\section{Porosity and structure of in-situ reduced $\mathrm{Al}_{2} \mathrm{O}_{3}$-based materials}

The textural and structural properties of in-situ reduced ma-terials were evaluated by $\mathrm{N}_{2}$-sorption measurements (Fig. $1 \mathrm{~A}$, Table 1 ), small angle X-ray diffraction (Fig. 1B) and high- resolution SEM observations (Fig. 2).

Fig. 1A reveals type IV isotherms for all in-situ reduced samples with $\mathrm{H}_{1}$-type hysteresis loops, suggesting the pres- ence of uniform cylindrically shaped channels $[41,42,58]$. All the capillary condensation steps are steep, indicating excel- lent uniform mesopores among the alumina frameworks even after high-temperature 
reduction. In addition, their PSD curves (inset fig.) are relatively sharp having one narrow peak present within the conventional range for uniform meso- porous materials (diameter between 8 and $13 \mathrm{~nm}$, Table 1). Moreover, all $\mathrm{Fe}, \mathrm{Ni}$ and $\mathrm{Fe}-\mathrm{Ni}$ alumina-based samples possess relatively high specific surface areas (range 100e200 $\mathrm{m}^{2} \mathrm{~g}^{-1}$, Table 1) and large pore volumes (range $0.22 \mathrm{e} 0.39 \mathrm{~cm}^{3} \mathrm{~g}^{-1}$, Table 1) in accordance with previous studies on similarly structured materials [52]. Compared to their calcined forms, in-situ reduced materials present smaller textural features (Table 1) that are attributed to thermal shrinkage and/or pore surface condensation of the $\mathrm{Al} \mathrm{O}$ matrix by dihydroxylation and/or dehydration under reduction medium [59].

It is worth noting that the textural properties, for a metal content of $10 \mathrm{wt} \%$, are slightly different depending on the presence of either Fe or both Fe and $\mathrm{Ni}$-nitrates in the synthesis batch. Upon increasing Fe content from 2.5 up to 7.5 wt\%, the adsorption branch of the hysteresis loop gradu- ally shifts to higher relative pressures, revealing larger pores (Table 1), the phenomenon being emphasized upon comparing monometallic $\mathrm{Fe}_{10 \%} \mathrm{Al}_{2} \mathrm{O}_{3}$ (curve a, Fig. $1 \mathrm{~A}$ ) to Fe- free $\mathrm{Ni}_{5 \%} \mathrm{Al}_{2} \mathrm{O}_{3}$ sample (curve e, Fig. 1A) displaying respec- tively the largest and smallest pores (Table 1 ). Such textural changes could not derive from neither calcination (in air) nor the $\mathrm{H}_{2}$ reduction procedures since all the materials have un- derwent the same exact thermal treatments. Basically, this increase in pore diameter could be related to the nitrates- baring water molecules (nanohydrate for Fe-precursor and hexahydrate for $\mathrm{Ni}$ precursor, mentioned in Section Preparation of mesoporous "one-pot" alumina based-materials) which can hydrolyze and produce $\mathrm{H}^{p}$ cations (via dissociation of $\mathrm{H}_{2} \mathrm{O}$ ) acidifying, therefore, the ethanol solution with successive widening of pores, as proposed in literature [58]. Such $\mathrm{pH}$ variations influence the balance at the organic/ inorganic interface and disturb the assembly process that contributes as well to the slight loss of surface area and pore volume seen in highly loaded Fe-samples $\left(\mathrm{Fe}_{10 \%} \mathrm{Al}_{2} \mathrm{O}_{3}\right.$ and $\mathrm{Fe}_{7.5 \%} \mathrm{Ni}_{2.5 \%} \mathrm{Al}_{2} \mathrm{O}_{3}$ ) compared to $\mathrm{Fe}_{5 \%} \mathrm{Ni}_{5 \%} \mathrm{Al}_{2} \mathrm{O}_{3}$ and $\mathrm{Fe}_{2.5 \%}-\mathrm{Ni}_{7.5 \%} \mathrm{Al}_{2} \mathrm{O}_{3}$ and highlighted upon comparing to $\mathrm{Ni}_{5 \%} \mathrm{Al}_{2} \mathrm{O}_{3}$. Despite these minor differences between samples, their textural values are sustaining for structured materials treated at elevated temperatures (700 O C) revealing high thermal resistance and emphasizing on their potential application for the high-temperature biogas reforming reaction.

Complementary to $\mathrm{N}_{2}$-sorption analysis, the small-angle XRD patterns of in-situ reduced samples (Fig. 1B) give a further evidence of the presence of ordered mesoporous structures. For all samples, there is a strong peak at circa $0.94^{\circ}$ and a weak one at $1.4^{\circ}$, which can be respectively ascribed to the (100) and (110) plane reflections of a well-organized 2D hexagonal structure (p6mm symmetry) $[41,42]$. A slight decrease in peak intensities is observed when going from $\mathrm{Fe}_{2.5 \%} \mathrm{Ni}_{7.5 \%} \mathrm{Al}_{2} \mathrm{O}_{3} \mathrm{Ni}_{5 \%} \mathrm{Al}_{2} \mathrm{O}_{3}$ (patterns $\mathrm{d}$ and e, Fig. 1B) to $\mathrm{Fe}_{10 \%} \mathrm{Al}_{2} \mathrm{O}_{3}$ (pattern a, Fig. 
1B), in direction of the improvement in the structuration degree of the alumina matrix, which is in harmony with nitrogen adsorption and desorption results.

The representative SEM images of in-situ reduced $\mathrm{Fe}_{10 \%} \mathrm{Al}_{2} \mathrm{O}_{3}$ (Fig. 2A) and $\mathrm{Fe}_{5 \%} \mathrm{Ni}_{5 \%} \mathrm{Al}_{2} \mathrm{O}_{3}$ (Fig. $2 \mathrm{~B}$ ) catalysts reveal that the grains appear as a bulk mass having a smooth ho- mogenous external morphology, without any cracks or de- fects, and a noticeable (porous) periodic organization. In agreement with porosity and diffraction data, the ordered hexagonal arrangement of pores along the [001] direction displaying honeycomb structure of mesopores (Fig. 2A') and the linear porous channel along the [110] direction (Fig. 2B') are clearly detectable. Besides, there is no evidence of exter- nally deposited iron or nickel metallic nanoparticles since there were no brilliant (light) colors on the gray alumina sur- face resulting from the diffusion of these higher electronic density elements. Their absence by SEM observations in- dicates the predominant presence of small metallic nanospecies embedded inside the alumina framework (as will be discussed in upcoming sections) and therefore, a high sin- tering resistance even after in-situ reduction at $700 \circ \mathrm{C}$.

\section{Reducibility of calcined $\mathrm{Al}_{2} \mathrm{O}_{3}$-based materials}

The TPR profiles of calcined mono- and bimetallic samples are presented respectively in Fig. $3 \mathrm{~A}$ and $\mathrm{B}$ and overall experi- mental $\mathrm{H}_{2}$-uptakes (200e900 O C range) estimated from these reduction profiles along with the relative contribution (in terms of consumed $\mathrm{H}_{2}$ ) of each peak are stated in Table 2.

Fig. $3 \mathrm{~A}$ shows that Fe and Ni species have different reducibility behaviors depending on their state of oxidation and their degree of interaction with the alumina matrix. For $\mathrm{Fe}_{10 \%} \mathrm{Al}_{2} \mathrm{O}_{3}$ (curve a, Fig. $3 \mathrm{~A}$ ), there is a main reduction peak at $450 \circ \mathrm{C}$ (accounting for $91 \%$ of the overall $\mathrm{H}_{2}$-uptake, Table 2), that is according to literature $[52,60 \mathrm{e} 62]$, in a temperature range between the reduction of $\mathrm{Fe}_{2} \mathrm{O}_{3}$ to $\mathrm{Fe}_{3} \mathrm{O}_{4}$ occurring around $300 \circ \mathrm{C}$, and of $\mathrm{Fe}_{3} \mathrm{O}_{4}$ to $\mathrm{Fe}$ taking place at temperatures above $600{ }^{\circ} \mathrm{C}$. The total $\mathrm{H}_{2}$-consumption at $450 \circ \mathrm{C}$ is around $800 \mathrm{mmol} \mathrm{g}^{-1}$ (Table 2), being larger than the stoichiometric value (expected for an Fe content of $10 \mathrm{wt} \%$ ) for the reduction of $\mathrm{Fe}_{2} \mathrm{O}_{3}$ to $\mathrm{Fe}_{3} \mathrm{O}_{4}\left(600 \mathrm{mmol} \mathrm{g}{ }^{-1}\right)$ while much smaller than that of $\mathrm{Fe}_{3} \mathrm{O}_{4}$ to $\mathrm{Fe}\left(2090 \mathrm{mmol} \mathrm{g}{ }^{-1}\right)$. Thus, this peak may be ascribed to the reduction of $\mathrm{Fe}_{2} \mathrm{O}_{3}$ into $\mathrm{Fe}_{3} \mathrm{O}_{4}$ where part of $\mathrm{Fe}_{3} \mathrm{O}_{4}$ could be further reduced into $\mathrm{Fe}^{0}[61,62]$. This means that the Fe- species in the $7000^{\circ} \mathrm{C}$ in-situ reduced catalyst are mostly in an oxidized form rather than the $\mathrm{Fe}^{0}$ form. Liu et al. [52] studied the real state of the surface elements species by XPS (X-ray photoelectron spectroscopy) for similarly prepared and acti- vated $\mathrm{Fe}-\mathrm{Al}_{2} \mathrm{O}_{3}$ catalysts and noted complete absence of peaks corresponding to $\mathrm{Fe}^{0}$ species in the total $\mathrm{Fe} 2 \mathrm{p}_{3 / 2}$ XPS spectra suggesting that no metallic Fe is formed on the surface of reduced materials. This could be associated to a strong interaction with the alumina substrate, induced from the preparation 
method, that stabilizes the oxide phase and suppresses its reduction to metal $\mathrm{Fe}^{0}$ [60e62]. The absence of metallic Fe-sites, as will be confirmed by wide-angle XRD patterns (section Dispersion, size and morphological aspects of supported Fe and $\mathrm{Ni}$ species), will have an impact on the catalytic activity of $\mathrm{Fe}_{10 \%} \mathrm{Al}_{2} \mathrm{O}_{3}$ catalyst (Section Catalytic performance in biogas dry reforming of $\mathrm{Al}_{2} \mathrm{O} 3$ based catalysts) since metallic sites are the active sites for catalyzing reforming reactions involving activation of $\mathrm{C}-\mathrm{H}$ and $\mathrm{C}-\mathrm{O}$ bonds [63].

The TPR profile of calcined $\mathrm{Ni}_{5 \%} \mathrm{Al}_{2} \mathrm{O}_{3}$ sample shows a main reduction peak at a rather high temperature ( $760 \circ \mathrm{C}$, curve e, Fig. $3 \mathrm{~A}$ ). Such type of profile, already described for "one-pot" synthesized Ni-alumina materials $[29,43]$, is typical of the reduction of oxidized $\mathrm{Ni}$ strongly interacting with the support, as in spinel mixed phases, generating small, catalytically active, $\mathrm{Ni}^{0}$ sites (Sections Catalytic performance in biogas dry reforming of $\mathrm{Al} 2 \mathrm{O} 3$ based catalysts and Section Dispersion, size and morphological aspects of supported Fe and Ni species).

Conversely to monometallic samples, the TPR profiles of the bimetallic $\mathrm{Fe}_{\mathrm{x} \%} \mathrm{Ni}_{(1-}$ x)\% $\mathrm{Al}_{2} \mathrm{O}_{3}$ ones (Fig. $3 \mathrm{~B}$ ) display two main reduction peaks with recognizable $\mathrm{H}_{2}-$ contributions (Table 2). For all these samples, the reduction peaks of both $\mathrm{Fe}$ (lower temperature peak, maxima in the 400e450 O $\mathrm{C}$ range) and $\mathrm{Ni}$ species (higher temperature peak, maxima in the 655e760 O $\mathrm{C}$ range) shift to lower temperatures compared with the corre- sponding peaks of $\mathrm{Fe}_{10 \%} \mathrm{Al}_{2} \mathrm{O}_{3}$ and $\mathrm{Ni}_{5 \%} \mathrm{Al}_{2} \mathrm{O}_{3}$. The integral area of the low-temperature peak increases linearly with the in- crease in $\mathrm{Fe}$ loading (or decrease in $\mathrm{Ni}$ loading) from $20 \%$ for $\mathrm{Fe}_{2.5 \%} \mathrm{Ni}_{7.5 \%} \mathrm{Al}_{2} \mathrm{O}_{3}$ to $38 \%$ for $\mathrm{Fe}_{7.5 \%} \mathrm{Ni}_{2.5 \%} \mathrm{Al}_{2} \mathrm{O}_{3}$ (Table 2). Even if expected, this observation emphasizes that (some) Fe-species in bimetallic materials are present in the same oxidation state as those in the single component $\mathrm{Fe}_{10 \%} \mathrm{Al}_{2} \mathrm{O}_{3}$ catalyst that undergo a subsequent (incomplete) reduction from $\mathrm{Fe}_{2} \mathrm{O}_{3}$ to $\mathrm{Fe}_{3} \mathrm{O}_{4}$ then to $\mathrm{Fe}^{0}$. Interestingly, the higher temperature reduction peak accounts for the majority of consumed $\mathrm{H}_{2} \quad(60 \mathrm{e} 80 \%$, Table 2) even for the Fe-richest $\mathrm{Fe}_{7.5 \%} \mathrm{Ni}_{2.5 \%} \mathrm{Al}_{2} \mathrm{O}_{3}$ sample. This indicates that in these Fe-Ni materials, the ma- jority of species are reduced at a temperature exceeding that noted in the $\mathrm{Fe}_{10 \%} \mathrm{Al}_{2} \mathrm{O}_{3}$ catalyst. Therefore, the high reduction temperature peak could not be fully ascribed to the reduction of $\mathrm{Ni}$ with strong $\mathrm{MSI}$ but rather to the reduction of mixed iron-nickel spinel phases with composition depending on the content of incorporated $\mathrm{Fe}$ and $\mathrm{Ni}$ elements [64]. The shift of the high-temperature peak towards lower temperatures with increase in $\mathrm{Ni}$ content (peak maxima around $750 \circ \mathrm{C}$ for $\mathrm{Fe}_{7.5 \%} \mathrm{Ni}_{2.5 \%} \mathrm{Al}_{2} \mathrm{O}_{3}$ compared to maxima around $655{ }^{\circ} \mathrm{C}$ for $\mathrm{Fe}_{2.5 \%} \mathrm{Ni}_{7.5 \%} \mathrm{Al}_{2} \mathrm{O}_{3}$ ) suggests some weakening of the $\mathrm{Ni}$ and $\mathrm{Al}_{2} \mathrm{O}_{3}$ interaction. This is mainly due to the presence of Fe that induces potential competition between nickel in the interac- tion with the alumina substrate because of the formation of iron-nickel alloys [52]. Also, an effect of accessibility of reducible species with 
changes of the chemical composition could be involved especially that the total $\mathrm{H}_{2}$-uptake was larger for $\mathrm{Fe}_{5 \%} \mathrm{Ni}_{5 \%} \mathrm{Al}_{2} \mathrm{O}_{3}$ as compared to $\mathrm{Fe}_{7.5 \%} \mathrm{Ni}_{2.5 \%} \mathrm{Al}_{2} \mathrm{O}_{3}$ and $\mathrm{Fe}_{2.5 \%} \mathrm{Ni}_{7.5 \%} \mathrm{Al}_{2} \mathrm{O}_{3}$ (Table 2). This ultimately suggests an enhanced dispersion of metallic species in the equimolar (molar Fe:Ni 1/4 1) composed sample (Section H2TPD and dispersion analysis in reduced $\mathrm{AL}_{2} \mathrm{O}_{3}$-based materials) and consequently a positive impact on catalysis (Section Catalytic performance in biogas dry reforming of $\mathrm{Al}_{2} \mathrm{O}_{3}$ based catalysts).

\section{$\mathrm{H}_{2}$-TPD and dispersion analysis in reduced $\mathrm{Al}_{2} \mathrm{O}_{3}$-based materials}

The $\mathrm{H}_{2}$-TPD experiments were performed over reduced cata- lysts to obtain information on the interaction between hydrogen molecules and metallic active sites as well as to quantitatively determine the amount of chemisorbed $\mathrm{H}_{2}$ that will provide a good estimate of metal dispersion (D\%). The related profiles for mono- and bimetallic catalysts are dis- played in Fig. $3 A^{\prime}, B^{\prime}$ and the calculated dispersion is mentioned in Table 2.

Compared to the $\mathrm{H}_{2}$-desorption profiles of monometallic $\mathrm{Ni}_{5 \%} \mathrm{Al}_{2} \mathrm{O}_{3}$ (curve e, Fig. $3 A^{\prime}$ ) that of the $\mathrm{Ni}$-free $\mathrm{Fe}_{10 \%} \mathrm{Al}_{2} \mathrm{O}_{3}$ catalyst (profile a, Fig. $3 A^{\prime}$ ) displays a broad signature that accounts for a low dispersion value (Table 2) with weak desorption peaks at around 540 and $820 \circ \mathrm{C}$. According to literature [61,65], the former peak could be attributed to $\mathrm{H}_{2-}$ desorption from surface exposed iron oxide-derived species and the latter corresponds to a desorption from subsurface layers of iron oxides incorporated in the alumina matrix. The low intensity of these peaks indicates a negligible reactivity of reduced iron species with $\mathrm{H}_{2}$ which in turn will influence catalytic reactivity (Section Catalytic performance in biogas dry reforming of $\mathrm{Al}_{2} \mathrm{O}_{3}$ based catalysts). A similar desorption classification could be adopted for the reduced nickel atoms in alumina with characteristic temperature ranges depending upon the type of reduced species. Over the monometallic Fe- free sample (curve e, Fig. 3A'), hydrogen atoms are being desorbed from (i) the exposed surfaces of highly dispersed $\mathrm{Ni}^{0}$ nanoparticles with high capacity of hydrogen dissociation at temperatures below $4500^{\circ} \mathrm{C}$ [54] and from (ii) the surfaces of $\mathrm{Ni}^{\circ}$ particles immersed in an alumina layer (subsurface species) at temperatures above $6000^{\circ} \mathrm{C}[66,67]$. The relative surface area of the high temperature desorption peaks (maxima at $880 \mathrm{e} 890^{\circ} \mathrm{C}$ ) is much larger than that at low temperatures (maxima around $200^{\circ} \mathrm{C}$ ) indicative of a population of metallic $\mathrm{Ni}$ species that is occluded within the alumina matrix (in the porous arrangement of the support), as will be verified on TEM images.

Concerning the TPD profiles of the $\mathrm{Fe}_{\mathrm{x} \%} \mathrm{Ni}_{(1-\mathrm{x}) \%} \mathrm{Al}_{2} \mathrm{O}_{3}$ series of catalysts, there is a significant change of the overall desorption behavior where several additional peaks especially at low (140e350 ${ }^{\circ} \mathrm{C}$ range) and intermediate (520e660 ${ }^{\circ} \mathrm{C}$ range) temperatures are observed (Fig. 3B'). For these catalysts, the identification of 
species with respect to their reactivity to $\mathrm{H}_{2}$ is more complex than for monometallic samples. It is catego- rized as a function of the desorption temperature peak where:

(i) peaks with maxima at very low temperature ranges $\left(140 \mathrm{e} 300^{\circ} \mathrm{C}\right)$ correspond to the desorption of $\mathrm{H}_{2}$ from exposed surfaces of highly reactive $\mathrm{Ni}$ particles, (ii) peaks at interme- diate range $\left(300 e 550^{\circ} \mathrm{C}\right.$ ) represent $\mathrm{H}_{2}$ desorbed from surfaces of $\mathrm{Ni}$-rich Fe-Ni alloys, (iii) peaks within the $550 \mathrm{e} 6600^{\circ} \mathrm{C}$ range are attributed to the desorption of $\mathrm{H}_{2}$ from Fe-rich Fe-Ni alloys and, (iv) desorbing peaks having maxima above $700 \circ \mathrm{C}$ char- acterize a more difficult desorption from the surface of lessaccessible (covered by alumina layers) Fe or Ni-species [60,66,67]. Indeed, for the mostly loaded Fe sample (curve b, Fig. 3B'), peaks at temperatures below 350 O C are non-visible compared to $\mathrm{Fe}_{2.5 \%} \mathrm{Ni}_{7.5 \%} \mathrm{Al}_{2} \mathrm{O}_{3}$ (curve d, Fig. $3 \mathrm{~B}^{\prime}$ ) and $\mathrm{Fe}_{5 \%} \mathrm{Ni}_{5 \%} \mathrm{Al}_{2} \mathrm{O}_{3}$ (curve C, Fig. 3B') due to the low amount of highly reactive $\mathrm{Ni}$ species. The presence of $\mathrm{Ni}$ in $\mathrm{Fe}_{7.5 \%} \mathrm{Ni}_{2.5 \%} \mathrm{Al}_{2} \mathrm{O}_{3}$ is rather attested by the desorption of $\mathrm{H}_{2}$ from Ni-rich alloys at 340 and $530^{\circ} \mathrm{C}$ and even from the desorption from Fe-Ni alloys at $6600^{\circ} \mathrm{C}$. As could be expected, the lack of Fe-rich alloys is clearly manifested for the $\mathrm{Ni}$ richest $\mathrm{Fe}_{2.5 \%} \mathrm{Ni}_{7.5 \%} \mathrm{Al}_{2} \mathrm{O}_{3}$ catalyst (curve d, Fig. 3B') by the absence of desorption peaks between 550 and $6600^{\circ} \mathrm{C}$, following a trend similar to that of mono- metallic $\mathrm{Ni}$-based samples (curves e-f, Fig. 3A'). Remarkably, the $\mathrm{Fe}_{5 \%} \mathrm{Ni}_{5 \%} \mathrm{Al}_{2} \mathrm{O}_{3}$ catalyst (curve c, Fig. 3B') presents $\mathrm{H}_{2}$ - desorption peaks, with close relative surfaces, in all temperature ranges. In this equimolar Fe:Ni catalyst, several types of species with a very high dispersion (Table 2), interfere in $\mathrm{H}_{2}$ adsorption (uptake being the highest amongst all catalysts, Table 2 ) and subsequent desorption. This highlights the fact that a proper amount of $\mathrm{Fe}$ and $\mathrm{Ni}$ is mandatory to generate different types of reactivity sites with improved dispersion (particularly when compared to $\left.\mathrm{Fe}_{2.5 \%} \mathrm{Ni}_{7.5 \%} \mathrm{Al}_{2} \mathrm{O}_{3}\right)$; factors being highly beneficial for enhanced catalytic performances.

\section{Catalytic performance in biogas dry reforming of $\mathrm{Al}_{2} \mathrm{O}_{3}$ - based catalysts}

Prior to catalytic evaluation, calcined mesoporous materials were in-situ reduced at $700 \circ \mathrm{C} / 2 \mathrm{~h}$ to generate metallic sites for methane reforming. The flow was then switched to that of reactants (GHSV of $36 \mathrm{~L} \mathrm{~g}^{-1} \mathrm{~h}^{-1}$ ) and the catalytic measurements were performed at $700{ }^{\circ} \mathrm{C}$ for $13 \mathrm{~h}$. The obtained con- version values $\left(\mathrm{XCH}_{4}\right.$, $\left.\mathrm{XCO}_{2}\right)$ and product ratios $\left(\mathrm{H}_{2}: \mathrm{CO}\right)$ are plotted as a function of time-on-stream in Fig. 4. Thermody- namic reactivity values evaluated using the HSC 7.1 Software for $C_{s}$ (carbon in solid phase)-assisted and $\mathrm{C}_{\mathrm{s}}$-free biogas dry reforming operations are also drawn on Fig. 4 (straight and straight-lines). Both types of simulations were performed in order to account for $\mathrm{C}_{s}$ deposition that is likely to occur especially when excess $\mathrm{CH}_{4}$ is present in the inlet feed. Ac- cording to thermodynamics, a much higher $\mathrm{CO}_{2}$ than $\mathrm{CH}_{4}$ conversion value (difference of $43.2 \%$ ) and an $\mathrm{H}_{2}$ : $\mathrm{CO}$ ratio 
close to 1.0 is expected when $C_{s}$ is not introduced as a possible product. This implies that under such conditions, the reforming reaction is highly selective towards methane dry reforming yielding an equimolar product ratio. When $\mathrm{C}_{\mathrm{s}}$ is considered, close $\mathrm{CO}_{2}$ and $\mathrm{CH}_{4}$ conversion values are antici- pated with an $\mathrm{H}_{2}$ :CO ratio greater than 1.0 (around 2.0) sug- gesting the high occurrence of secondary reactions involving methane consumption and subsequent $\mathrm{H}_{2}$ production. At high reaction temperatures of $700 \circ \mathrm{C}$, methane decomposition re- mains the most (thermodynamically) favorable carbon pro- ducing reaction responsible for conversion and selectivity variations.

Catalytic results of monometallic "one-pot" synthesized catalysts (Fig. 4A,B and C) show that $\mathrm{Ni}$ incorporated in mes- oporous alumina (curve e) is more active than $\mathrm{Fe}$ (curve a), even for a metal content that is twice less $\left(\mathrm{Ni}_{5 \%} \mathrm{Al}_{2} \mathrm{O}_{3}\right.$ compared to $\mathrm{Fe}_{10 \%} \mathrm{Al}_{2} \mathrm{O}_{3}$ ). Respective intrinsic $\mathrm{XCH}_{4}$ and $X \mathrm{XO}_{2}$ values over $\mathrm{Ni}_{5 \%} \mathrm{Al}_{2} \mathrm{O}_{3}$ are 39 and $64 \%$ compared to 12 and $29 \%$ over $\mathrm{Fe}_{10 \%} \mathrm{Al}_{2} \mathrm{O}_{3}$. With respect to bimetallic "one-pot" synthe- sized catalysts (Fig. $4 \mathrm{~A}^{\prime}, \mathrm{B}^{0}$ and $\mathrm{C}^{0}$ ), performances are found to be stable with time-on-stream with reactivity and selectivity levels differing with respect to catalyst composition. It is important to note that a substitution of only $2.5 \mathrm{wt} \%$ Fe by $2.5 \mathrm{wt} \% \mathrm{Ni}$ is significantly capable of ameliorating the reac- tivity and the stability of Fe-species (curve b, Figs. $A^{0}, B^{0}$ ) where; more than the double in the conversion values of $\mathrm{Fe}_{10 \%} \mathrm{Al}_{2} \mathrm{O}_{3}$ are measured over $\mathrm{Fe}_{7.5 \%} \mathrm{Ni}_{2.5 \%} \mathrm{Al}_{2} \mathrm{O}_{3}$. The amelioration in reactivity levels is significantly noted when 5 wt\% Fe is substituted by 5 wt\% Ni (curve c, Figs. $\mathrm{A}^{0}, \mathrm{~B}^{0}$ ). The $\mathrm{Fe}_{5 \%} \mathrm{Ni}_{5 \%} \mathrm{Al}_{2} \mathrm{O}_{3}$ catalyst recorded the highest performance of all cata- lysts and the closest to the maximum thermodynamically expected one (curve e, Fig. 4A and B). The co-presence of $5 \mathrm{wt} \% \mathrm{Ni}$ along with $5 \mathrm{wt} \% \mathrm{Fe}$ is beneficial to both $\mathrm{CH}_{4}$ and $\mathrm{CO}_{2}$ conversions compared to the catalyst with same $\mathrm{Ni}$ content but without Fe incorporation (curve e, Fig. $4 \mathrm{~A}$ and $\mathrm{B}$ ). The reactivity of $\mathrm{Fe}_{5 \%} \mathrm{Ni}_{5 \%} \mathrm{Al}_{2} \mathrm{O}_{3}$ even exceeded that of $\mathrm{Fe}_{2.5 \%}-\mathrm{Ni}_{7.5 \%} \mathrm{Al}_{2} \mathrm{O}_{3}$ (curve d, Fig. $4 \mathrm{~A}^{0}, \mathrm{~B}^{0}$ ) in spite of a higher nickel content. Moreover, it is surprising to note that the most reactive $\mathrm{Fe}_{5 \%} \mathrm{Ni}_{5 \%} \mathrm{Al}_{2} \mathrm{O}_{3}$ catalyst displays performances that follow the same trend (higher $\mathrm{CO}_{2}$ than $\mathrm{CH}_{4}$ conversions) as that predicted thermodynamically for a $\mathrm{C}_{\mathrm{s}}$-free simulation (Fig. 4, dashed-lines). This designates that this catalyst is operating a dry reforming reaction in absence of severe $C_{s}$ deposition, as will be verified in the carbon characterization section over spent catalysts. Indeed, from a selectivity perspective (Fig. $4 C, C^{0}$ ), the product ratio is close to 1.0 for $\mathrm{Fe}_{5 \%} \mathrm{Ni}_{5 \%} \mathrm{Al}_{2} \mathrm{O}_{3}$ (curve c, Fig. $4 \mathrm{C}^{\prime}$ ) all along the $13 \mathrm{~h}$ of test.

Thus, the performances of our $\mathrm{Fe}_{5 \%} \mathrm{Ni}_{5 \%} \mathrm{Al}_{2} \mathrm{O}_{3}$ catalyst appear highly promising, and this stands also when compared to literature performances obtained by other research teams over $\mathrm{Al}_{2} \mathrm{O}_{3}$-based catalysts, even at higher $\mathrm{Ni}$ loadings. $\mathrm{By}$ comparison, addition of 11 wt\% $\mathrm{NiO}$ and $20 \mathrm{wt} \% \mathrm{CeO}_{2}$ on impregnated $\mathrm{TiO}_{2}$ on $\mathrm{Al}_{2} \mathrm{O}_{3}$ mixed oxide [24] was found beneficial when conducting the same reaction 
but under less drastic operation conditions $\left(\mathrm{CH}_{4} / \mathrm{CO}_{2}\right.$ molar ratio of 1.5 compared to 1.8 used in our study). In addition, high $\mathrm{CH}_{4}$ and $\mathrm{CO}_{2}$ conversions were reported over a $\mathrm{Ni}$ (8 wt\%) impregnated on combined $\mathrm{CeO}_{2}-\mathrm{Al}_{2} \mathrm{O}_{3}$ catalyst but, isothermal stability measurements showed slight deactivation, even over the most reactive $\mathrm{Ni} / \mathrm{CeO}_{2}-\mathrm{Al}_{2} \mathrm{O}_{3}$ catalyst, in spite of mild biogas reforming conditions $\left(\mathrm{CH}_{4} / \mathrm{CO}_{2}\right.$ inlet ratio of 1.5) [22]. Besides, biogas reforming performances as good as ours were attained on $\mathrm{Ni}_{8 \%} / \mathrm{Al}_{2} \mathrm{O}_{3}$ catalyst featuring an equilibrium deposition filtration synthesis method [25], but the preparation routes were quite complex with extensive energy and time- consuming (several steps) pre- and post-synthesis catalyst treatments. Therefore, the above "one-pot" $\mathrm{Fe}_{5 \%} \mathrm{Ni}_{5 \%} \mathrm{Al}_{2} \mathrm{O}_{3}$ catalyst, obtained by direct (one-step) synthesis and by using a mono-metallic standard type of support (alumina), represents a highly effective candidate for biogas dry reforming, offering the advantage of avoiding the usage of post-synthesis treatments and expensive secondary metal incorporation.

The importance of incorporating $\mathrm{Ni}$ along with Fe for an enhanced performance of Fe species upon considering appropriate amounts of $\mathrm{Ni}$ to Fe is illustrated in Fig. 5. This figure shows on the same graph the levels of methane con-version (average values from stability tests) and dispersion values (calculated from TPD experiments) as a function of $\mathrm{Fe}: \mathrm{Ni}$ molar content in bimetallic catalysts. The correlation combining dispersion and reactivity levels obtained by increasing $\mathrm{Ni}$ content from 2.5 up to 5 wt\% is in fact predict- able since an enrichment of $\mathrm{Ni}$, with a highly maintained dispersion, generates $\mathrm{Ni}^{0}$ sites that are more important for catalysis (than Fe sites) resulting in higher reactivity levels. An additional substitution of Fe by $\mathrm{Ni}$ till reaching a $\mathrm{Fe}: \mathrm{Ni}$ ratio of 0.33 results in an opposite trend where; the dispersion de- creases and consequently methane conversion declines (Fig. 5). Recalling TPD curves (Fig. 3B'), the reduced $\mathrm{Fe}_{5 \%} \mathrm{Ni}_{5 \%} \mathrm{Al}_{2} \mathrm{O}_{3}$ catalyst retains the larger amount (than any other mono or bimetallic catalyst) of strong hydrogenbinding sites characterized by $\mathrm{H}_{2}$-desorption peaks with maxima in the temperature range of $140 \mathrm{e} 350^{\circ} \mathrm{C}$. It has been reported that such sites of nickel species are favorable for facilitating chemisorption of hydrogen atoms generated from dissociative adsorption of hydrogen molecules $[56,66,68]$. Moreover, the stable adsorption of hydrogen atoms on such strong $\mathrm{H}_{2}$-binding sites will tentatively promote the dissociative adsorption of methane on reduced metallic Ni sites, known as the rate- determining step for reforming reactions involving methane [69]. Thus, $\mathrm{Fe}_{5 \%} \mathrm{Ni}_{5 \%} \mathrm{Al}_{2} \mathrm{O}_{3}$ with many strong hydrogen-binding sites shows a faster (and higher) methane adsorption capacity due to an easier accessibility of methane towards these, particularly active sites. Therefore, a stable performance of Fe species with reactivity levels higher than those achieved over Fe-free and Ni-free samples is possibly realized by combining Fe to an equimolar amount of $\mathrm{Ni}$. 


\section{Dispersion, size and morphological aspects of supported Fe and Ni species}

Structural information on the deposited metal species in calcined, in-situ reduced and spent catalysts was gained from wide-angle X-ray diffraction. The patterns are presented in Fig. 6 and the estimated particle sizes at the various succes- sive stages of samples preparation are listed in Table 3.

With respect to structures, all calcined materials present a comparable XRD pattern (Fig. 6B) with weak broad diffraction peaks characteristic of a $\mathrm{g}-\mathrm{Al}_{2} \mathrm{O}_{3}$ phase (ICDD file \# 10e0425) with small crystalline domains. The patterns are similar, independently on the $\mathrm{Fe}$ and/or $\mathrm{Ni}$ content. The notable absence of apparent diffraction peaks attributable to iron or nickel crystalline phases reveals an amorphous character and an extremely high dispersion of species in the mesoporous alumina skeleton. Even if their presence is not detectable in the calcined materials, it was indeed confirmed by their cor- responding TPR profiles (discussed previously in Section Reducibilty of calcined $\mathrm{AL}_{2} \mathrm{O}_{3}$-based materials).

Upon heating at $700 \mathrm{O} \mathrm{C}$ in $\mathrm{H}_{2}$, weak peaks attributable to metallic nickel become identifiable in all Ni-containing sam- ples (patterns b-e, Fig. 6B). The stability of the fully reduced $\mathrm{Ni}^{0}$ with face centered cubic (FCC) unit cell (ICDD file \# 65e0380) is verified even after catalytic run (patterns b-f, Fig. 6C) due to (i) the preserved reduction state of nickel nanoparticles and to (ii) the scarcely modified peak intensities of crystalline $\mathrm{Ni}^{0}$. Accordingly, the mean sizes of the crystalline domains esti- mated from peak widths are small (a slight increase is noted with the increase in Ni content independently on Fe content, Table 3) after in-situ reduction and their sizes remain very close to those found after catalysis. This reveals a high $\mathrm{Ni}^{0}$ resistance to sintering owing to the special advantages of the "one-pot" preparation method. Comparable stability effects were recently claimed in the case of "one-pot" synthesized oxide-based catalysts tested in dry [36e38], steam [70] and in combined methane reforming $[29,43]$ but such types of ma- terials were never considered yet in biogas dry reforming operated under excess methane at a high temperature of $700^{\circ} \mathrm{C}$.

Moreover, in the XRD signatures of Ni-containing catalysts (patterns b-f, Fig. 6), additional diffraction peaks correspond-ing to the phase transition of the alumina skeleton from amorphous (Fig. 6A) to (at least partial) crystalline g- $\mathrm{Al}_{2} \mathrm{O}_{3}$ are visible (Fig. 6B) resulting from the high temperature applied in the course of reduction. The crystallization phenomenon is slightly accentuated after biogas dry reforming (Fig. 6C), due to longer exposure to heating, yet no major change is apparent (particularly, thin XRD peaks demonstrating the formation of bulky crystalline phases are not noted) despite severe catalytic conditions. This is an evidence of the excellent structural resistance of the organized alumina-based networks. It is noteworthy that XRD peaks of crystalline metallic $\mathrm{Fe}^{0}$ are not visible in neither insitu reduced nor in spent $\mathrm{Ni}$-free $\mathrm{Fe}_{10 \%} \mathrm{Al}_{2} \mathrm{O}_{3}$ catalyst (pattern a, Fig. 6B and C) where; only peaks of magnetite $\mathrm{Fe}_{3} \mathrm{O}_{4}$ oxide (FCC unit cell, ICDD file \# 19e0629) 
are detected. This absence of $\mathrm{Fe}^{0}$ diffraction peaks confirms the TPR reducibility behavior of $\mathrm{Fe}_{10 \%} \mathrm{Al}_{2} \mathrm{O}_{3}$ (Section Reducibilty of calcined $\mathrm{AL}_{2} \mathrm{O}_{3}$-based materials) attesting on the difficult reduction of $\mathrm{Fe}_{2} \mathrm{O}_{3}$ to $\mathrm{Fe}^{0}$ (ending at the stage of $\mathrm{Fe}_{3} \mathrm{O}_{4}$ phase) owing to strong iron-alumina interaction. Moreover, $\mathrm{g}-\mathrm{Al}_{2} \mathrm{O}_{3}$ peaks are also not detectable in the pattern of the $\mathrm{Ni}$-free $\mathrm{Fe}_{10 \%} \mathrm{Al}_{2} \mathrm{O}_{3}$ catalyst even after $13 \mathrm{~h}$ on stream at $700 \circ \mathrm{C}$. Observations similar to ours were already mentioned in the literature for monometallic $\mathrm{Fe}-\mathrm{Al}_{2} \mathrm{O}_{3}$ samples [56]; yet not clearly addressed. We tentatively associate it to the for-mation, during synthesis, of a phase consisting of $\mathrm{Fe}_{2} \mathrm{O}_{3}$ and $\mathrm{g}-\mathrm{Al}_{2} \mathrm{O}_{3}$ (recently mentioned in literature in the form of amor-phous $\mathrm{Fe}_{2} \mathrm{O}_{3} \cdot \mathrm{Al}_{2} \mathrm{O}_{3}$ [67]) from the incorporation of $\mathrm{Fe}$ ions within the alumina substrate. Under high-temperature reduction, some of the $\mathrm{Fe}_{2} \mathrm{O}_{3}$ species detach from the alumina then undergo the reduction (yet incomplete) into $\mathrm{Fe}_{3} \mathrm{O}_{4}$ whereas, the excess $\mathrm{Fe}_{2} \mathrm{O}_{3}$ remaining strongly attached to $\mathrm{Al}_{2} \mathrm{O}_{3}$ hampers the crystallization of alumina into well- defined crystalline $\mathrm{g}-\mathrm{Al}_{2} \mathrm{O}_{3}$, a phase clearly detected in all our Ni-containing catalysts (Fig. 6B and C). Regarding XRD patterns, an increase in $\mathrm{Ni}$ content causes an absence of magnetite diffraction peaks and an increase in the intensity of the g- $\mathrm{Al}_{2} \mathrm{O}_{3}$ peaks (patterns $\mathrm{b}-\mathrm{f}$, Fig. $6 \mathrm{~B}$ and $\mathrm{C}$ ). This could be explained based on TPR and TPD analyses identifying the formation of Fe-Ni alloys. The copresence of both $\mathrm{Fe}$ and $\mathrm{Ni}$ reduces the formation of free $\mathrm{Fe}_{3} \mathrm{O}_{4}$ due to the alloying of $\mathrm{Fe}$ with $\mathrm{Ni}$ and simultaneously limits the interaction of $\mathrm{Fe}$ with $\mathrm{Al}_{2} \mathrm{O}_{3}$ allowing, therefore, alumina to crystallize. The absence of XRD signals linked to Fe-Ni alloys

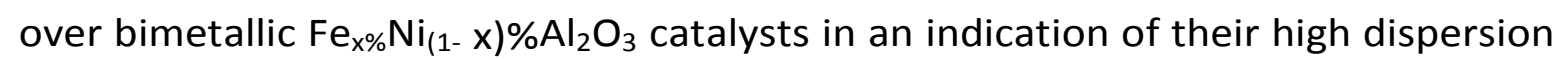
as was indeed verified based on dispersion results (Table 2) showing an enhancement of overall dispersion upon addition of $\mathrm{Ni}$ (in place of $\mathrm{Fe}$ ) until reaching the optimum content in the equimolar $\mathrm{Fe}_{5 \%} \mathrm{Ni}_{5 \%} \mathrm{Al}_{2} \mathrm{O}_{3}$ catalyst.

The high stability of the alumina matrix along with the preservation of welldispersed nanoparticles at high- temperature biogas dry reforming is also confirmed by microtome TEM images (Fig. 7). It is obvious that the ordered hexagonal arrangement of the porous network and its uni-form channel system is preserved, both perpendicular to [001] (Fig. 7A,B,C) and along [110] (Fig. 7A', $\mathrm{B}^{0}, \mathrm{C}^{\prime}$ ) grain directions. The average sizes obtained from TEM observations are close to those estimated from XRD peaks (Table 3), enlightening once more on the high resistance of $\mathrm{Ni}^{0}$ to sintering even after $13 \mathrm{~h}$ on stream at $700 \mathrm{O} \mathrm{C}$. The excellent thermal resistance of all spent catalysts is also attested by the persistence of small angle XRD peaks in the patterns of all spent catalysts (Fig. 8). A direct comparison between lattice parameters (Table 4) shows only slight shifts in values upon passing respectively from in- situ reduced to spent materials (i.e. from $11.5 \AA$ to $11.7 \mathrm{Q}$ for $\mathrm{Fe}_{5 \%} \mathrm{Ni}_{5 \%} \mathrm{Al}_{2} \mathrm{O}_{3}$ ). Such shift in the $d$ spacing and subsequently in the lattice parameter to higher values (Table 4) suggests a small enlargement in the pore diameter after catalysis. This could be ascribed to an additional 
crystallization of the alumina matrix, into the $\mathrm{g}-\mathrm{Al}_{2} \mathrm{O}_{3}$ phase (Fig. $6 \mathrm{C}$ ), in line with longer heating treatment.

In the search of stable Fe-based catalysts, the major challenge to confront, especially when the catalyst is subjected to high-temperature treatments, is the limitation of segregation for maintaining active surface areas [57,58]. Our partially reduced (detected by XRD) yet detached from alumina Fe $\mathrm{O}$ species could be subjected to such a problem. To enhance the segregation resistance, we have tried to introduce the active phase (Fe) and the structuring agent (P123 Pluronic triblock copolymer) in a same synthesis batch to provide a confine- ment effect. Such a preparation method was found to be a key parameter for ensuring the stability of Ni-based catalysts [29,43], a technique to our knowledge, never considered for Fe- based catalysts as an approach to limit segregation. In spite of the preservation of the porous arrangement of the alumina matrix in the spent $\mathrm{Fe}$ loaded catalyst (Fig. 7A and $\mathrm{B}$ ); the segregation of $\mathrm{Fe}_{3} \mathrm{O}_{4}$ species manifests and contributes (in part) to the deactivation of Ni-free $\mathrm{Fe}_{10 \%} \mathrm{Al}_{2} \mathrm{O}_{3}$ catalyst (Fig. 9A, $\mathrm{A}^{0}$ ). Iron enriched zones clearly appear on microtome images as localized dark stripes (Fig. 9A) constituted of iron aggregates embedded inside the porous network of the solid (Fig. 9A'). Such observations confirm those regarding the porous network of $\mathrm{Fe}_{10 \%} \mathrm{Al}_{2} \mathrm{O}_{3}$ (high resolutions images, Fig. $7 \mathrm{~A}, \mathrm{~A}^{0}$ ) that appear empty of small dark dots representative of non-homogeneously distributed particles. As expected, the segregation of $\mathrm{Ni}^{0}$ nanoparticles in spent $\mathrm{Ni}_{5 \%} \mathrm{Al}_{2} \mathrm{O}_{3}$ is not evident but regardless a bright homogenous morphology of the catalyst is seen instead (Fig. 7C). The analysis of the localization of species in the highly active and time-on-stream stable $\mathrm{Fe}_{5 \%} \mathrm{Ni}_{5 \%} \mathrm{Al}_{2} \mathrm{O}_{3}$ catalyst highlights again on the deacti- vation mode of Fe species that becomes limited in presence of $\mathrm{Ni}$. The segregation encountered in $\mathrm{Fe}_{10 \%} \mathrm{Al}_{2} \mathrm{O}_{3}$ is no longer a deactivating factor when $5 \mathrm{wt} \%$ Fe was substituted by an equivalent $\mathrm{Ni}$ amount. The segregation of iron becomes limited in spent $\mathrm{Fe}_{5 \%} \mathrm{Ni}_{5 \%} \mathrm{Al}_{2} \mathrm{O}_{3}$ and surprisingly the shape of the (few) remaining $\mathrm{Fe}_{2} \mathrm{O}_{3}$-based stripes is also affected (Fig. 9B). Rather than having core-full chain-like segregates as those seen in spent $\mathrm{Fe}_{10 \%} \mathrm{Al}_{2} \mathrm{O}_{3}$ (Fig. 9A, $\mathrm{A}^{\prime}$ ), the iron stripes in the bimetallic catalyst have hollow core chain forms resulting from less segregated free iron species that preferentially alloy with $\mathrm{Ni}$ when both metals are co-introduced in the same preparation batch and treated to high temperatures. Contin- uous work is in progress to complete these results.

\section{Study of carbon deposition over spent biogas dry reforming $\mathrm{Al}_{2} \mathrm{O}_{3}$-based catalysts}

The spent catalysts were characterized by several techniques to notify coke deposits. Combined TGA and DSC (Fig. 10A and B) carried out in the air, between $3000^{\circ} \mathrm{C}$ and $900^{\circ} \mathrm{C}$, was applied to recognize the type of deposited carbonaceous 
spe- cies based on their oxidation temperatures (principally $\mathrm{sp}^{2}$ (grapheme, nanotubes) and $\mathrm{sp}^{3}$ (graphite) carbon types) [71,72].

The first significant information provided by TGA is the overall $\mathrm{C}_{(\mathrm{s})}$ content over all spent catalysts that is not exceeding $10 \mathrm{wt} \%$ even over the most $\mathrm{C}_{(\mathrm{s})}$-loaded sample (maximum amount is $6 \mathrm{wt} \%$ ). This is in accordance with the abovediscussed reactivity data showing a selective dry reforming of methane behavior $\left(\mathrm{H}_{2}\right.$ :CO close to 1$)$ over the most performing catalysts. Besides high reactivity levels, our "one-pot" synthesized mesoporous catalysts show very high carbon resistance along with high-temperature biogas dry reforming, at least as high or even better than those described in the few existing reports on actual simulated biogas reforming catalysts. Carbon content exceeded 12 wt\% over a mesoporous $\mathrm{Ni}$ modified by tungsten $\mathrm{Ni}_{5 \%} \mathrm{~W}_{5 \%} \mathrm{Al}_{2} \mathrm{O}_{3}$ catalyst even when operated under less drastic biogas reforming conditions (inlet molar feed $\mathrm{CH}_{4} / \mathrm{CO}_{2} \quad 1 / 4$ 1:1) [73]. Similarly, for an equimolar gaseous inlet feed, carbon contents exceeded 15 wt\% over spent mesoporous $\mathrm{Ni}$-Fe (Co or $\mathrm{Cu}$ )-CaO- $\mathrm{ZrO}_{2}$ catalysts [74]. For a biogas reforming operation $\left(\mathrm{CH}_{4} / \mathrm{CO}_{2} 1 / 41.5\right)$ close to that adopted in this study, a $\mathrm{Ni}_{8 \%} \mathrm{Al}_{2} \mathrm{O}_{3}$ catalyst prepared via standard post-impregnation over commercial alumina support displayed a $7 \mathrm{wt} \% \mathrm{C}_{(\mathrm{s})}$ content after a short exposure to reaction medium [25]. Such resistance to carbon deposition could be related to the advantages of the preparation methods enabling a high dispersion of metallic nano- particles inside the mesoporous structure of the support protecting them from heavy $\mathrm{C}_{(\mathrm{s})}$ accumulation, as confirmed by XRD and TEM data. Secondly, the coke content is directly proportional to Fe content (or inversely proportional to $\mathrm{Ni}$ content) where the highest amount is recorded over spent $\mathrm{Fe}_{10 \%} \mathrm{Al}_{2} \mathrm{O}_{3}$ (curve a, Fig. 10A) and the lowest one (almost ab- sent) over the Fe-free catalyst (curve e, Fig. 10A). This difference in the overall amount of carbonaceous deposits is dependent on the type of the site over which the dissociation of $\mathrm{CO}_{2}$ can occur. The formation of oxygen atoms, subsequently to $\mathrm{CO}_{2}$ activation, is a key to generate an oxidation path of $\mathrm{C}_{(\mathrm{s})}$ (originating from $\mathrm{CH}_{4}$ decomposition) into $\mathrm{CO}$ reducing, therefore, carbon accumulation [75]. Due to the predominance of oxide-based iron species in $\mathrm{Fe}_{10 \%} \mathrm{Al}_{2} \mathrm{O}_{3}$ (Fig. 6), $\mathrm{CO}_{2}$ activation is totally inhibited (compared to a slight activation of $\mathrm{CH}_{4}$ ) on the surfaces of oxide species whereas, all reactions rates $\left(\mathrm{CH}_{4}, \mathrm{CO}_{2}\right.$ and $\mathrm{C}_{(\mathrm{s})}$ gasification) would be of the same order on (active) reduced $\mathrm{Ni}^{0}$ sites. The reason why $\mathrm{CO}_{2}$ is affected more than $\mathrm{CH}_{4}$ could be linked to its activation that should occur over reduced metallic sites whereas $\mathrm{CH}_{4}$ could undergo a partial activation on oxidized surfaces [76]. In view of that, a compromise be- tween $\mathrm{Fe}$ and $\mathrm{Ni}$ contents appears essential to design a low cost and highly reactive catalyst with low carbon deposition especially that the latter effect is important from an industrial point of view since carbon deposition is known to potentially lead to reactors blockage with time. 
Concerning DSC profiles (Fig. 10B), the peaks disclose two main types of cokederived species described as (i) weakly stable amorphous $\mathrm{Ca}$ ( $\mathrm{sp}^{2} \mathrm{C}$-atoms, graphene-like species, peak $300 \mathrm{e} 450 \mathrm{O}$ C) and (ii) Cb (C-nanotubes, peak $450 \mathrm{e} 550 \mathrm{O}$ C) [72]. The absence of exothermic peaks with maxima above $550 \circ \mathrm{C}$ dictates that no carbon in these samples is present in the form of crystalline Cg graphite, known to be the most harmful to catalytic stability due to encapsulation of active metallic sites [71]. DSC peaks are almost absent over spent $\mathrm{Ni}_{5 \%} \mathrm{Al}_{2} \mathrm{O}_{3}$ (curve e, Fig. 10B), in accordance with their very small $C_{(s)}$ content. For spent monometallic $\mathrm{Fe}_{10 \%} \mathrm{Al}_{2} \mathrm{O}_{3}$ cata- lyst, the single DSC peak at 415 O C corresponds to a population of carbonaceous graphene deposits with a sponge-like morphology, shown on SEM images in Fig. $11 \mathrm{~A}, \mathrm{~A}^{0}$, and the two peaks over spent bimetallic catalysts reveal the co- existence of both $\mathrm{sp}^{2} \mathrm{C}$-atoms and $\mathrm{C}$-nanotubes. Indeed, on the SEM images of spent $\mathrm{Fe}_{5 \%} \mathrm{Ni}_{5 \%} \mathrm{Al}_{2} \mathrm{O}_{3}$ (Fig. $11 \mathrm{~B}, \mathrm{~B}^{\prime}$ ), small C- like sponges domains and short-carbon filaments are clearly identified on the external surface of the alumina-based grains, some grains appearing more covered than others. Particularly, the DSC peaks of $\mathrm{Ni}$ rich $\mathrm{Fe}_{2.5 \%} \mathrm{Ni}_{7.5 \%} \mathrm{Al}_{2} \mathrm{O}_{3}$ are centered above

$500{ }^{\circ} \mathrm{C}$ (curve d, Fig. 10B) being close to those of Fe-rich $\mathrm{Fe}_{10 \%} \mathrm{Al}_{2} \mathrm{O}_{3}$ and $\mathrm{Ni}_{2.5 \%} \mathrm{Fe}_{7.5 \%} \mathrm{Al}_{2} \mathrm{O}_{3}$ (curves a-b, Fig. 10B) rather than those noted for the oxidation of carbon from $\mathrm{Ni}_{5 \%} \mathrm{Al}_{2} \mathrm{O}_{3}$ catalysts taking place at around $300 \circ \mathrm{C}$ (curve e, Fig. 10B). This is most probably due to some hindrance in the accessibility to active $\mathrm{Ni}^{0}$ sites potentially caused by some (unfavorable) iron deposition over nickel during preparation and thermal activation. The majority of carbon originating from $\mathrm{CH}_{4}$ decom- position over accessible Fe-sites retards the maximum of the dynamic oxidation process to higher temperatures. This could also provide an explanation for the decrease in reactivity levels and dispersion values (D\%) noted upon comparing $\mathrm{Fe}_{2.5 \%} \mathrm{Ni}_{7.5 \%} \mathrm{Al}_{2} \mathrm{O}_{3}$ to optimally composed bimetallic $\mathrm{Fe}_{5 \%} \mathrm{Ni}_{5 \%} \mathrm{Al}_{2} \mathrm{O}_{3}$ catalyst (Fig. 5). Even if they exist in trivial amounts, the coke deposits over Ni-free and bimetallic spent catalysts are only present as non-deactivating graphene and some nanotubes are shown on external surfaces of alumina grains (Fig. 11).

The amorphous state of carbon deposits in spent catalysts is also confirmed by Raman spectroscopy. Signals were only obtained for the spent $C_{(s)}$ richest $\mathrm{Fe}_{10 \%} \mathrm{Al}_{2} \mathrm{O}_{3}$ and bimetallic $\mathrm{Fe}_{\mathrm{x} \%} \mathrm{Ni}_{(1-\mathrm{x}) \%} \mathrm{Al}_{2} \mathrm{O}_{3}$ catalysts, where spent $\mathrm{Ni}_{5 \%} \mathrm{Al}_{2} \mathrm{O}_{3}$ catalysts with lower amounts of $\mathrm{C}_{(\mathrm{s})}$ deposition have a widely exposed (poorly covered by carbon) alumina surface which causes, during Raman experimentation, a strong fluorescence back- ground that hampers correct data detection [77]. The main bands in the spectra (Fig. 12) are characteristic of C atoms in $\mathrm{sp}^{2}$ carbon networks with high degree of order (graphitic carbon, G-band, $1601 \mathrm{~cm}^{-1}$ ) and of a disordered structural mode of carbon species (D-band, $1312 \mathrm{~cm}^{-1}$ ) [77e79]. The signal strength of the D-band compared to the G-band (in- tensity ratio: $I_{D} / I_{G}$ ) is an indicator of the crystalline degree and/ or presence of defects in the carbon species, 
the smaller the ratio (less than 1), the higher the degree of structural ordering $[77,79]$. The ratio higher than unity for all $\mathrm{Fe}_{10 \%} \mathrm{Al}_{2} \mathrm{O}_{3}$ and $\mathrm{Fe}_{\mathrm{x}} \% \mathrm{Ni}_{(1-\mathrm{x}) \%} \mathrm{Al}_{2} \mathrm{O}_{3}$ spent catalysts (range from 1.33 to 1.21 passing from patterns a till d, Fig. 12) coordinates with the assumption of the disordered character of the carbon deposits rather than well-ordered crystalline graphitic. Finally, the absence of XRD signal attributable to graphitic deposits (expected around 2Q 290), even for $C_{(s)}$ richest $\mathrm{Fe}_{10 \%} \mathrm{Al}_{2} \mathrm{O}_{3}$ (pattern a, Fig. 6C) concludes on the negligible content of crystalline carbon deduced from TGA/DSC and Raman data.

\section{Conclusions}

The aim of this work was to evaluate and enhance the performance of costefficient iron based-catalysts in dry reforming of a model biogas mixture $\left(\mathrm{CH}_{4} / \mathrm{CO}_{2}\right.$ $1 / 4$ 1.8) via simple approaches without adopting extensive preparation routes or applying noble metals. $\mathrm{Fe}, \mathrm{Ni}$ and $\mathrm{Fe}-\mathrm{Ni}$ in alumina catalysts were designed following a straightforward "one-pot" evaporation-induced self-assembly method in presence of both structuring agent and active phase. After preparation of samples and in-situ $\mathrm{H}_{2}$-reduction, all the solids presented $2 \mathrm{D}$ hexagonal arrangement of pores and a successful incorporation of metals within the structured alumina matrix. Ni nanoparticles showed more reactive performances towards biogas reforming than $\mathrm{Fe}$ at $700 \mathrm{O} \mathrm{C}$ for $13 \mathrm{~h}$ on stream. Respective $\mathrm{CH}_{4}$ and $\mathrm{CO}_{2}$ conversions over $\mathrm{Ni}_{5 \%} \mathrm{Al}_{2} \mathrm{O}_{3}$ were 4 and 2.3 times higher than those recorded over monometallic $\mathrm{Fe}_{10 \%} \mathrm{Al}_{2} \mathrm{O}_{3}$. The deactivation of the latter (Ni-free) catalyst attributed to a strong interaction of iron with alumina that lead to an incomplete reduction into metallic $\mathrm{Fe}^{0}$ (preferred phase for catalysis) but rather to $\mathrm{Fe}_{3} \mathrm{O}_{4}$ oxides that tend to segregate, under high temperature effects, into poorly dispersed iron-like strips inducing losses in the total active surface area. A partial substitution of $\mathrm{Fe}$ by $\mathrm{Ni}$ yielded bimetallic catalysts, specifically $\mathrm{Fe}_{5 \%} \mathrm{Ni}_{5 \%} \mathrm{Al}_{2} \mathrm{O}_{3}$, having improved dispersion and catalytic performance compared to monometallic $\mathrm{Fe} \quad-$ and $\mathrm{Ni}$ Al O . Indeed, a $10 \%$ increase in $\mathrm{CH} 4$ conversion and a $20 \%$ increase in $\mathrm{CO}_{2}$ conversion were obtained over the optimum bimetallic $\mathrm{Fe}_{5 \%} \mathrm{Ni}_{5 \%} \mathrm{Al}_{2} \mathrm{O}_{3}$ catalyst compared to Fe-free $\mathrm{Ni}_{5 \%} \mathrm{Al}_{2} \mathrm{O}_{3}$. The formation of Fe-Ni alloys in the bimetallic, $\mathrm{Fe}_{5 \%} \mathrm{Ni}_{5} \mathrm{Al}_{2} \mathrm{O}_{3}$, catalyst acted as barriers towards the segregation of Fe species where the majority of nanoparticles remained confined within the pores of the support after $13 \mathrm{~h}$ of testing. The stabilization of iron species by $\mathrm{Ni}$ together with the beneficial effect of confinement in the structured alumina support are found to be key factors in protecting against segregation and coking due to steric constraints. In light of their textural, structural and catalytic performances, "one-pot" mesoporous Fe, modified by Ni catalysts, represent good candidates for catalyzing syngas for diverse simulated biogas mixtures. 


\section{Acknowledgments}

The authors are sincerely grateful to the ERANET EU-FP7 initiative, the national ANR (France) and CNRS-L (Lebanon) agencies for their financial support through the SOL-CARE (Energy-065, 2016e2019) project (JC-ENERGY-2014 first call). The authors would like to thank Ms. Sandra Casale for SEM and TEM observations and Dr. Jean-Marc Kraftt for his help in setting Raman instrumentation. The authors are appreciative to Pr. Nasser Hoteit and Dr. Hassan Hamieh (Lebanese Petroleum Administration, Lebanon) for fruitful scientific discussions.

\section{References}

[1] Pakhare D, Spivey J. A review of dry $\left(\mathrm{CO}_{2}\right)$ reforming of methane over noble metal catalysts. Chem Soc Rev 2014;43:7813e37.

[2] Gao Y, Jiang J, Meng Y, Yan F, Aihemaiti A. A review of recent developments in hydrogen production via biogas dry reforming. Energy Convers Manag 2018;171:133e55.

[3] Liu JL, Li XS, Zhu X, Li K, Shi C, Zhu AM. Renewable and high- concentration syngas production from oxidative reforming of simulated biogas with low energy cost in a plasma shade. Chem Eng J 2013;234:240e6.

[4] Kim HY, Park JN, Henkelman G, Kim JM. Design of a highly nano-dispersed Pd$\mathrm{MgO} / \mathrm{SiO}_{2}$ composite catalyst with multifunctional activity for $\mathrm{CH}_{4}$ reforming. ChemSusChem 2012;5:1474e81.

[5] Erisman JW, Sutton MA, Galloway J, Klimont Z, Winiwarter W. How a century of ammonia synthesis changed the world? Nat Geosci 2008;1:636e9.

[6] Olah GA, Prakash GS, Goeppert A, Czaun M, Mathew T. Self- sufficient and exclusive oxygenation of methane and its source materials with oxygen to methanol via metgas using oxidative bi-reforming. J Am Chem Soc 2013;135:10030e1.

[7] Olah GA, Goeppert A, Prakash GKS. Beyond oil and gas: the methanol economy 2011, John Wiley and Sons.

[8] Kawi S, Kathiraser Y, Ni J, Oemar U, Li Z, Saw ET. Progress in synthesis of highly active and stable nickel-based catalysts for carbon dioxide reforming of methane. ChemSusChem 2015;8:3556e75.

[9] Goula MA, Charisiou ND, Siakavelas G, Tzounis L, Tsiaoussis I, Panagiotopoulou P, Yentekakis IV. Syngas production via the biogas dry reforming reaction over $\mathrm{Ni}$ supported on zirconia modified with $\mathrm{CeO}_{2}$ or $\mathrm{La}_{2} \mathrm{O}_{3}$ catalysts. Int J Hydrogen Energy 2017;42:13724e40.

[10] Habibi N, Wang Y, Arandiyan $\mathrm{H}$, Rezaei M. Effect of substitution by $\mathrm{Ni}$ in $\mathrm{MgAl}_{2} \mathrm{O}_{4}$ spinel for biogas dry reforming. Int J Hydrogen Energy 2017;42:24159e68.

[11] Cruz PL, Navas-Anguita Z, Iribarren D, Dufour J. Exergy analysis of hydrogen production via biogas dry reforming. Int J Hydrogen Energy 2018;43:11688e95.

[12] Aresta $\mathrm{M}$, Dibenedetto $\mathrm{A}$, Angelini A. The changing paradigm in $\mathrm{CO}_{2}$ utilization. $\mathrm{J} \mathrm{CO}_{2}$ Utiliz 2013;3:65e73. 
[13] Li D, Nakagawa Y, Tomishige K. Methane reforming to synthesis gas over Ni catalysts modified with noble metals. Appl Catal Gen 2011;408:1e24.

[14] Pakhare D, Schwartz V, Abdelsayed V, Haynes D, Shekhawat D, Puston J, Spivey J. Kinetic and mechanistic study of dry $\left(\mathrm{CO}_{2}\right)$ reforming of methane over Rhsubstituted $\mathrm{La}_{2} \mathrm{Zr}_{2} \mathrm{O}_{7}$ pyrochlores. J Catal 2014;316:78e92.

[15] Moral A, Reyero I, Alfaro C, Bimbela F, Gandı́a LM. Syngas production by means of biogas catalytic partial oxidation and dry reforming using Rh-based catalysts. Catal Today 2018;299:280e8.

[16] Benito M, Ortiz I, Rodríguez L, Muñoz G. Ni-Co bimetallic catalyst for hydrogen production in sewage treatment plants: biogas reforming and tars removal. Int J Hydrogen Energy 2015;40:14456e68.

[17] Arbag H, Yasyerli S, Yasyerli N, Dogu G, Dogu T. Enhancement of catalytic performance of $\mathrm{Ni}$ based mesoporous alumina by $\mathrm{Co}$ incorporation in conversion of biogas to synthesis gas. Appl Catal Env 2016;198:254e65.

[18] Rostrupnielsen JR, Hansen JHBJ. $\mathrm{CO}_{2}$-reforming of methane over transition metals. J Catal 1993;144:38e48.

[19] Mesrar F, Kacimi M, Liotta LF, Puleo F, Ziyad M. Syngas production from dry reforming of methane over $\mathrm{Ni} /$ perlite catalysts: effect of zirconia and ceria impregnation. Int J Hydrogen Energy 2018;42:17142e55.

[20] Charisiou ND, Siakavelas G, Tzounis L, Sebastian V, Monzon A, Baker MA, Goula MA. An in depth investigation of deactivation through carbon formation during the biogas dry reforming reaction for $\mathrm{Ni}$ supported on modified with $\mathrm{CeO}_{2}$ and $\mathrm{La}_{2} \mathrm{O}_{3}$ zirconia catalysts. Int J Hydrogen Energy 2018;43:18955e76.

[21] Moura-Nickel CD, Costa RL, Ferreira SRS, Moreiza RDFPM, Jose, HJ. Ni- $\mathrm{Y}_{2} \mathrm{O}_{3}-\mathrm{Al}_{2} \mathrm{O}_{3}$ aerogel catalysts with high coke deposition resistance for syngas production by biogas reforming. Int J Hydrogen Energy 2019;44:11861e71.

[22] Charisiou ND, Siakavelas G, Papageridis KN, Baklavaridis A, Tzounis L, Avraam DG, Goula MA. Syngas production via the biogas dry reforming reaction over nickel supported on modified with $\mathrm{CeO}_{2}$ and/or $\mathrm{La}_{2} \mathrm{O}_{3}$ alumina catalysts. J Nat Gas Chem 2016;31:164e83.

[23] Le Sache, E, Santos JL, Smith TJ, Centeno MA, Arellano- Garcia H, Odriozola JA, Reina TR. Multicomponent $\mathrm{Ni}-\mathrm{CeO}_{2}$ nanocatalysts for syngas production from $\mathrm{CO}_{2} / \mathrm{CH}_{4}$ mixtures. J $\mathrm{CO}_{2}$ Utiliz 2018;25:68e78.

[24] Rosha P, Mohapatra SK, Mahla SK, Dhir A. Biogas reforming for hydrogen enrichment by ceria decorated over nickel catalyst supported on titania and alumina. Int J Hydrogen Energy 2018;43:21246e55.

[25] Goula MA, Charisiou ND, Papageridis KN, Delimitis A, Pachatouridou E, Iliopoulou EF. Nickel on alumina catalysts for the production of hydrogen rich mixtures via the biogas dry reforming reaction: influence of the synthesis method. Int J Hydrogen Energy 2015;40:9183e200. 
[26] Djaidja A, Libs S, Kiennemann A, Barama A. Characterization and activity in dry reforming of methane on $\mathrm{NiMg} / \mathrm{Al}$ and $\mathrm{Ni} / \mathrm{MgO}$ catalysts. Catal Today 2006;113:194e200.

[27] Eltejaei H, Bozorgzadeh HR, Towfighi J, Omidkhah MR, Rezaei M, Zanganeh R, Zamaniyan A, Ghalam AZ. Methane dry reforming on $\mathrm{Ni} / \mathrm{Ce}_{0.75} \mathrm{Zr}_{0.25} \mathrm{O}_{2}-\mathrm{MgAl}_{2} \mathrm{O}_{4}$ and $\mathrm{Ni} /$ $\mathrm{Ce}_{0.75} \mathrm{Zr}_{0.25} \mathrm{O}_{2}$-g-alumina: effects of support composition and water addition. Int J Hydrogen Energy 2012;37:4107e18.

[28] Mondal KC, Choudhary VR, Joshi UA. $\mathrm{CO}_{2}$ reforming of methane to syngas over highly active and stable supported $\mathrm{CoO}_{\mathrm{x}}$ (accompanied with $\mathrm{MgO}, \mathrm{ZrO}_{2}$ or $\mathrm{CeO}_{2}$ ) catalysts. Appl Catal Gen 2007;316:47e52.

[29] Jabbour K, Massiani P, Davidson A, Casale S, El Hassan N. Ordered mesoporous "one-pot" synthesized $\mathrm{Ni}-\mathrm{Mg}(\mathrm{Ca})-\mathrm{Al}_{2} \mathrm{O}_{3}$ as effective and remarkably stable catalysts for combined steam and dry reforming of methane (CSDRM). Appl Catal Env 2017;201:527e42.

[30] Kaydouh MN, El Hassan N, Davidson A, Casale S, El Zakhem H, Massiani P. Highly active and stable Ni/SBA-15 catalysts prepared by a "two solvents" method for dry reforming of methane. Microporous Mesoporous Mater 2016;220:99e109.

[31] Kaydouh MN, El Hassan N, Davidson A, Casale S, El Zakhem H, Massiani P. Effect of the order of $\mathrm{Ni}$ and Ce addition in SBA-15 on the activity in dry reforming of methane. C R Chim 2015;18:293e301.

[32] Daoura O, Kaydouh MN, El-Hassan N, Massiani P, Launay F, Boutros M. Mesocellular silica foam-based $\mathrm{Ni}$ catalysts for dry reforming of $\mathrm{CH}_{4}$ (by $\left.\mathrm{CO}_{2}\right)$. J $\mathrm{CO}_{2}$ Utiliz 2018;24:112e9.

[33] Karam L, Casale S, El Zakhem H, El Hassan N. Tuning the properties of nickel nanoparticles inside SBA-15 mesopores for enhanced stability in methane reforming. $\mathrm{J} \mathrm{CO}_{2}$ Utiliz 2017;17:119e24.

[34] Zhang S, Muratsugu S, Ishiguro N, Tada M. Ceria-doped Ni/ SBA-16 catalysts for dry reforming of methane. ACS Catal 2013;3:1855e64.

[35] Xu L, Zhao H, Song H, Chou L. Ordered mesoporous alumina supported nickel based catalysts for carbon dioxide reforming of methane. Int J Hydrogen Energy 2012;37:7497e511.

[36] Tao K, Shi L, Ma Q, Zeng C, Kong C, Wu M, Chen L, Zhou S, Hu Y, Tsubaki N. Methane reforming with carbon dioxide over mesoporous nickel-alumina composite catalyst. Chem Eng J 2013;221:25e31.

[37] Wang N, Xu Z, Deng J, Shen K, Yu X, Qian W, Chu W, Wei F. One-pot synthesis of ordered mesoporous NiCeAl oxide catalysts and a study of their performance in methane dry reforming. ChemCatChem 2014;6:1470e80.

[38] Fang X, Peng C, Peng H, Liu W, Xu X, Wang X, Li C, Zhou W. Methane dry reforming over coke-resistant mesoporous $\mathrm{Ni}-\mathrm{Al}_{2} \mathrm{O}_{3}$ catalysts prepared by evaporationinduced self- assembly method. ChemCatChem 2015;7:3753e62. 
[39] $\mathrm{Xu} \mathrm{L}$, Song $\mathrm{H}$, Chou L. Carbon dioxide reforming of methane over ordered

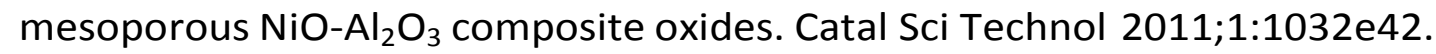

[40] Jabbour K, El Hassan N, Davidson A, Massiani P, Casale S. Characterizations and performances of $\mathrm{Ni}$ /diatomite catalysts for dry reforming of methane. Chem Eng J 2015;264:351e8.

[41] Morris SM, Fulvio PF, Jaroniec MM. Ordered mesoporous alumina-supported metal oxides. J Am Chem Soc 2008;130:15210e6.

[42] Yuan Q, Yin AX, Luo C, Sun LD, Zhang YW, Duan WT, Liu HC, Yan CH. Facile synthesis for ordered mesoporous g-aluminas with high thermal stability. J Am Chem Soc 2008;130:3465e72.

[43] Jabbour K, El Hassan N, Davidson A, Casale S, Massiani P. Factors affecting the long-term stability of mesoporous nickel-based catalysts in combined steam and dry reforming of methane. Catal Sci Technol 2016;6:4616e31.

[44] Andersson MP, Bligaard T, Kustov A, Larsen KE, Greeley J, Johannessen T, Christensen $\mathrm{CH}, \mathrm{N} \varnothing$ rskov JK. Toward computational screening in heterogeneous catalysis: pareto- optimal methanation catalysts. J Catal 2006;239:501e6.

[45] Ober JA. Mineral commodity summaries 2016. Reston, VA:

U.S. Geological survey; 2016.

[46] Ren J, Qin X, Yang JZ, Qin ZF, Guo HL, Lin JY, Li Z. Methanation of carbon dioxide over $\mathrm{Ni}-\mathrm{M} / \mathrm{ZrO}_{2}(\mathrm{M} 1 / 4 \mathrm{Fe}, \mathrm{Co}, \mathrm{Cu})$ catalysts: effect of addition of a second metal. Fuel Process Technol 2015;137:204e11.

[47] Kustov AL, Frey AM, Larsen KE, Johannessen T, Nørskov JK, Christensen CH. CO methanation over supported bimetallic Ni-Fe catalysts: from computational studies towards catalyst optimization. Appl Catal Gen 2007;320:98e104.

[48] Tian D, Liu Z, Li D, Shi H, Pan W, Cheng Y. Bimetallic Ni-Fe total-methanation catalyst for the production of substitute natural gas under high pressure. Fuel 2013;104:224e9.

[49] Hwang S, Lee J, Hong UG, Baik JH, Koh DJ, Lim H, Song IK. Methanation of carbon dioxide over mesoporous $\mathrm{Ni}-\mathrm{Fe}-\mathrm{Ru}-\mathrm{Al}_{2} \mathrm{O}_{3}$ xerogel catalysts: effect of ruthenium content. J Ind Eng Chem 2013;19:698e703.

[50] Theofanidis SA, Batchu R, Galvita VV, Poelman H, Marin GB. Carbon gasification from Fe-Ni catalysts after methane dry reforming. Appl Catal Env 2016;185:42e55.

[51] Theofanidis SA, Galvita VV, Sabbe M, Poelman H, Detavernier C, Marin GB. Controlling the stability of a Fe-Ni reforming catalyst: structural organization of the active components. Appl Catal Env 2017;209:405e16.

[52] Liu Q, Qiao Y, Tian Y, Gu F, Zhong Z, Su F. Ordered mesoporous Ni-Fe-Al catalysts for $\mathrm{CO}$ methanation with enhanced activity and resistance to deactivation. Ind Eng Chem Res 2017;56:9809e20.

[53] Satthawong R, Koizumi N, Song C, Prasassarakich P. Comparative study on $\mathrm{CO}_{2}$ hydrogenation to higher hydrocarbons over Fe-based bimetallic catalysts. Top Catal 2014;57:588e94. 
[54] Liu Q, Gao J, Zhang M, Li H, Gu F, Xu G, Zhong Z, Su F. Highly active and stable Ni/g$\mathrm{Al}_{2} \mathrm{O}_{3}$ catalysts selectively deposited with $\mathrm{CeO}_{2}$ for $\mathrm{CO}$ methanation. RSC Adv 2014;4:16094e103.

[55] Liu Q, Gao J, Gu F, Lu X, Liu Y, Li H, Zhong Z, Liu B, Xu G, Su F. One-pot synthesis of ordered mesoporous Ni-V-Al catalysts for $\mathrm{CO}$ methanation. J Catal 2015;326:127e38.

[56] Phromprasit J, Powell J, Wongsakulphasatch S, Kiatkittipong W, Bumroongsakulsawat $\mathrm{P}$, Assabumrungrat. $\mathrm{H}_{2}$ production from sorption enhanced steam reforming of biogas using multifunctional catalysts of $\mathrm{Ni}$ over $\mathrm{Zr}-, \mathrm{Ce}-$ and Lamodified CaO sorbents. S. Chem Eng J 2017;313:1415e25.

[57] Izquierdo U, Barrio VL, Requies J, Cambra JF, Gü emez MB, Arias PL. Tri-reforming: a new biogas process for synthesis gas and hydrogen production. Int J Hydrogen Energy 2013;38:7623e31.

[58] Cai W, Yu J, Anand C, Vinu A, Jaroniec MM. Facile synthesis of ordered mesoporous alumina and alumina-supported metal oxides with tailored adsorption and framework properties. Chem Mater 2011;23:1147e57.

[59] Chen SY, Tang CY, Lee JF, Jang LY, Tatsumi T, Cheng SJ. Effect of calcination on the structure and catalytic activities of titanium incorporated SBA-15. J Mater Chem 2011;21:2255e65.

[60] Wan HJ, Wu BS, Zhang CH, Xiang HW, Li YW, Xu BF, Yi F. Study on Fe- $\mathrm{Al}_{2} \mathrm{O}_{3}$ interaction over precipitated iron catalyst for Fischer-Tropsch synthesis. Catal Commun 2007;8:1538e45.

[61] Zhou L, Enakonda LR, Saih Y, Loptain S, Gary D, Del-Gallo P, Basset JM. Catalytic methane decomposition over $\mathrm{Fe}_{-} \mathrm{Al}_{2} \mathrm{O}_{3}$. ChemSusChem 2016;9:1243e8.

[62] Pineau A, Kanari N, Gaballah I. Kinetics of reduction of iron oxides by $\mathrm{H}_{2}$ : part I: low temperature reduction of hematite. Thermochim Acta 2006;447:89e100.

[63] Wei J, Iglesia E. Mechanism and site requirements for activation and chemical conversion of methane on supported $\mathrm{Pt}$ clusters and turnover rate comparisons among noble metals. J Phys Chem B 2004;108:4094e103.

[64] Ren SB, Qin JH, Wang $C Y, X u B L$, Fan $Y N$, Chen Y. Influence of nickel salt precursors on the hydrogenation activity of $\mathrm{Ni} / \mathrm{g}-\mathrm{Al}_{2} \mathrm{O}_{3}$ catalyst. Chin J Catal 2007;28:651e6.

[65] Wan HJ, Wu BS, An X, Li TZ, Tao ZC, Xiang HW, Li YW. Effect of $A 1_{2} \mathrm{O}_{3}$ binder on the precipitated iron-based catalysts for Fischer-Tropsch synthesis. J Nat Gas Chem 2007;16:130e8.

[66] Velu S, Gangwal SK. Synthesis of alumina supported nickel nanoparticle catalysts and evaluation of nickel metal dispersions by temperature programmed desorption. Solid State Ionics 2006;177:803e11.

[67] Bang Y, Park S, Han SJ, Yoo J, Song JH, Choi JH, Kang KH, Song IK. Hydrogen production by steam reforming of liquefied natural gas (LNG) over mesoporous $\mathrm{Ni} / \mathrm{Al}_{2} \mathrm{O}_{3}$ catalyst prepared by an EDTA-assisted impregnation method. Appl Catal Env 2016;180:179e88. 
[68] Bang Y, Han SJ, Yoo J, Choi JH, Lee JK, Song JH, Lee J, Song IK. Hydrogen production by steam reforming of simulated liquefied natural gas (LNG) over nickel catalyst supported on mesoporous phosphorus-modified alumina xerogel. Appl Catal Env 2014;148:269e80.

[69] Trimm DL. The steam reforming of natural gas: problems and some solutions. Stud Surf Sci Catal 1987;36:39e50.

[70] Shen W, Komatsubara K, Hagiyama T, Yoshida A, Naito S. Steam reforming of methane over ordered mesoporous $\mathrm{Ni}$ - Mg-Al oxides. Chem Commun (J Chem Soc Sect D) 2009;42:6490e2.

[71] Luo JZ, Yu ZL, Ng CF, Au CT. $\mathrm{CO}_{2} / \mathrm{CH}_{4}$ reforming over $\mathrm{Ni}-\mathrm{La}_{2} \mathrm{O}_{3} / 5 \mathrm{~A}$ : an investigation on carbon deposition and reaction steps. J Catal 2000;194:198e210.

[72] Guo J, Lou H, Zheng XM. The deposition of coke from methane on a Ni/MgAl $\mathrm{O}_{4}$ catalyst. Carbon 2007;45:1314e21.

[73] Arbag H, Yasyerli S, Yasyerli N, Dogu G, Dogu T, Osojnik Crnivec IG, Pintar A. Coke minimization during conversion of biogas to syngas by bimetallic tungsten-nickel incorporated mesoporous alumina synthesized by the one-pot route. Ind Eng Chem Res 2015;54:2290e301.

[74] Wang C, Zhang $\mathrm{Y}$, Wang $\mathrm{Y}$, Zhao $\mathrm{Y}$. Comparative studies of non-noble metal modified mesoporous $\mathrm{M}-\mathrm{Ni}-\mathrm{CaO}-\mathrm{ZrO}_{2}\left(\mathrm{M} 1 \frac{1}{4} \mathrm{Fe}, \mathrm{Co}, \mathrm{Cu}\right)$ catalysts for simulated biogas dry reforming. Chin J Chem Eng 2017;35:113e20.

[75] Nguyen TH, Lamacz A, Krzton A, Liszka B, Djegga- Mariadassou G. Partial oxidation of methane over $\mathrm{Ni}^{0} / \mathrm{La}_{2} \mathrm{O}_{3}$ bifunctional catalyst III. Steady state activity of methane total oxidation, dry reforming, steam reforming and partial oxidation. Sequences of elementary steps. Appl Catal Env 2016;182:385e91.

[76] Shamsi A. Carbon formation on $\mathrm{Ni}-\mathrm{MgO}$ catalyst during reaction of methane in the presence of $\mathrm{CO}_{2}$ and CO. Appl Catal Gen 2004;277:23e30.

[77] Chen CY, Li HX, Davis ME. Studies on mesoporous materials:

I. Synthesis and characterization of MCM-41. Microporous Mater 1993;2:17e26.

[78] Liu D, Quek XY, Cheo WNE, Lau R, Borgna A, Yang Y. MCM-41 supported nickel-based bimetallic catalysts with superior stability during carbon dioxide reforming of methane: effect of strong metal-support interaction. J Catal 2009;266:380e90.

[79] Che M, Vedrine JC. Characterization of solid materials and heterogeneous catalysts. Wiley-VCH; 2012. p. $64 \mathrm{e}$. 


\section{Tables}

Table 1: Textural properties of calcined and in situ reduced samples

\begin{tabular}{|c|c|c|c|c|c|c|c|}
\hline \multirow{3}{*}{$\begin{array}{l}\text { Samples } \\
\text { Fe10\%Al203 }\end{array}$} & \multirow{3}{*}{\begin{tabular}{|r} 
Metal \\
weight \%
\end{tabular}} & \multirow{2}{*}{\multicolumn{2}{|c|}{$\begin{array}{l}\text { BET surface area }\left(\mathrm{m}^{2}\right. \\
\left.\mathrm{g}^{-1}\right) \\
\text { calc. }^{\text {a }} \text { red. }{ }^{\mathrm{b}}\end{array}$}} & \multicolumn{2}{|c|}{ Pore volume (m3 g-1) } & \multirow{2}{*}{\multicolumn{2}{|c|}{$\begin{array}{c}\text { Average pore } \\
\text { diameter }(\mathrm{nm})^{\mathrm{c}}\end{array}$}} \\
\hline & & & & \multirow{2}{*}{$\begin{array}{c}\text { calc. }^{\text {a }} \\
0.33\end{array}$} & \multirow{2}{*}{ red. $^{b}$} & & \\
\hline & & 166 & 99 & & & $9.9 \pm 6$ & $12.8 \pm 7$ \\
\hline Fe7.5\%Ni2.5\%Al2O3 & $\begin{array}{l}\text { 7.5 Fe, } \\
2.5 \mathrm{Ni}\end{array}$ & 172 & 107 & 0.38 & 0.23 & $9.2 \pm 5$ & $11.1 \pm 6$ \\
\hline $\mathrm{Fe}_{5 \%} \mathrm{Ni}_{5 \%} \mathrm{Al}_{2} \mathrm{O}_{3}$ & $\begin{array}{l}5.0 \mathrm{Fe} \\
5.0 \mathrm{Ni}\end{array}$ & 198 & 138 & 0.40 & 0.31 & $9.2 \pm 5$ & $9.4 \pm 5$ \\
\hline Fe2.5\%Ni7.5\%Al2O3 & $\begin{array}{l}2.5 \mathrm{Fe}, \\
7.5 \mathrm{Ni}\end{array}$ & 244 & 164 & 0.47 & 0.39 & $9.0 \pm 4$ & $8.4 \pm 5$ \\
\hline $\mathrm{Ni}_{5 \%} \mathrm{Al}_{2} \mathrm{O}_{3}$ & $5.0 \mathrm{Ni}$ & 185 & 121 & 0.37 & 0.27 & $9.5 \pm 6$ & $9.6 \pm 5$ \\
\hline \multicolumn{8}{|c|}{$\begin{array}{l}\text { a Textural values of synthesized (calcined) samples }(600 \text { o } \mathrm{C} / 5 \mathrm{~h}) \text {. } \\
\text { b Textural values of calcined samples after in-situ } \mathrm{H}_{2} \text {-reduction }(700 \circ \mathrm{C} / 2 \mathrm{~h}) \text {. } \\
\text { c Average pore diameter } \pm \text { standard deviation from the maxima. }\end{array}$} \\
\hline
\end{tabular}

Table 2: $\mathrm{H}_{2}$-chemisorption properties of calcined samples.

\begin{tabular}{|c|c|c|c|c|}
\hline \multirow[b]{2}{*}{ Samples } & \multicolumn{3}{|c|}{$\mathrm{H}_{2}$-TPR analysis } & \multirow[b]{2}{*}{$\begin{array}{l}\mathrm{H}_{2} \text {-TPD } \\
\text { analysis } \\
\text { Dispersion } \\
(\mathrm{D} \%)^{\mathrm{C}}\end{array}$} \\
\hline & $\begin{array}{c}\text { Pea } \\
\text { k } \\
\text { temp. } \\
\text { (o C) }\end{array}$ & $\begin{array}{c}\text { Relative } \\
\text { contribution } \\
(\%)^{\mathrm{a}}\end{array}$ & $\begin{array}{c}\text { Total } \\
\mathrm{H}_{\mathbf{2}^{-}} \\
\text {uptake } \\
\left(\mathrm{mmol}^{-1}\right)^{\mathbf{b}} \\
\mathrm{g}^{-}\end{array}$ & \\
\hline
\end{tabular}




\begin{tabular}{|c|c|c|c|c|}
\hline \multirow{2}{*}{ Fe10\%Al2O3 } & $\begin{array}{c}4 \\
50\end{array}$ & 91 & $4^{80}$ & 5.2 \\
\hline & $\begin{array}{r}7 \\
74\end{array}$ & 9 & & \\
\hline \multirow{2}{*}{$\begin{array}{l}\text { Fe7.5\%Ni2.5\%Al2 } \\
03\end{array}$} & $\begin{array}{c}4 \\
50\end{array}$ & 38 & $5^{99}$ & 18.1 \\
\hline & $\begin{array}{c}7 \\
50\end{array}$ & 62 & & \\
\hline \multirow{2}{*}{$\mathrm{Fe}_{5 \%} \mathrm{Ni}_{5 \%} \mathrm{Al}_{2} \mathrm{O}_{3}$} & $\begin{array}{l}4 \\
30\end{array}$ & 30 & $36^{11}$ & 17.4 \\
\hline & $\begin{array}{c}7 \\
10\end{array}$ & 70 & & \\
\hline \multirow{2}{*}{$\begin{array}{l}\text { Fe2.5\%Ni7.5\%Al2 } \\
03\end{array}$} & $0^{4}$ & 20 & $1^{95}$ & 10.8 \\
\hline & $\begin{array}{r}6 \\
55^{6}\end{array}$ & 80 & & \\
\hline $\mathrm{Ni}_{5 \%} \mathrm{Al}_{2} \mathrm{O}_{3}$ & $\begin{array}{r}7 \\
60\end{array}$ & 100 & $8^{82}$ & 17.0 \\
\hline
\end{tabular}

Table 3: Average particle size of nickel species in in-situ reduced $(7000$ $\mathrm{C} / 2 \mathrm{~h}, \mathrm{H}_{2} / \mathrm{Ar}$ ) and spent (700 $\mathrm{O} \mathrm{C} / 13 \mathrm{~h}, \mathrm{CH}_{4} / \mathrm{CO}_{2} / \mathrm{Ar} 1 / 41.8 / 1 / 14, \mathrm{P} 1 / 41 \mathrm{~atm}$, GHSV $1 / 436 \mathrm{Lg}^{\mathbf{1} 1} \mathrm{~h}^{\mathbf{i}}{ }^{1}$ ) catalysts.

\begin{tabular}{|l|c|c|c|}
\hline \multirow{2}{*}{ Samples } & \multicolumn{2}{|c|}{ Reduced, $\varnothing \mathrm{Ni}^{0}(\mathrm{~nm})$} & $\begin{array}{c}\text { Spent, } \varnothing \\
\mathrm{Ni}^{0}(\mathrm{~nm})\end{array}$ \\
\cline { 2 - 4 } & $\mathrm{XRD}^{\mathrm{a}}$ & $\mathrm{XRD}^{\mathrm{a}}$ & $\mathrm{TEM}$ \\
\hline $\mathrm{Fe}_{10 \%} \mathrm{Al}_{2} \mathrm{O}_{3}$ & $\mathrm{e}$ & $\mathrm{e}$ & $\mathrm{e}$ \\
\hline $\mathrm{Fe}_{7.5 \%} \mathrm{Ni}_{2.5 \%} \mathrm{Al}_{2} \mathrm{O}_{3}$ & $\mathrm{e}$ & 3.2 & $\mathrm{e}$ \\
\hline $\mathrm{Fe}_{5 \%} \mathrm{Ni}_{5 \%} \mathrm{Al}_{2} \mathrm{O}_{3}$ & 4.5 & 4.7 & 5.4 \\
\hline $\mathrm{Fe}_{2.5 \%} \mathrm{Ni}_{7.5 \%} \mathrm{Al}_{2} \mathrm{O}_{3}$ & 5.0 & 5.0 & $\mathrm{e}$ \\
\hline $\mathrm{Ni}_{5 \%} \mathrm{Al}_{2} \mathrm{O}_{3}$ & 3.4 & 3.5 & 3.2 \\
\hline
\end{tabular}

a Calculated using Scherrer's equation at $2 Q \frac{1}{1 / 4} 51.80$ for $\mathrm{tl}$ 


\section{Figures}
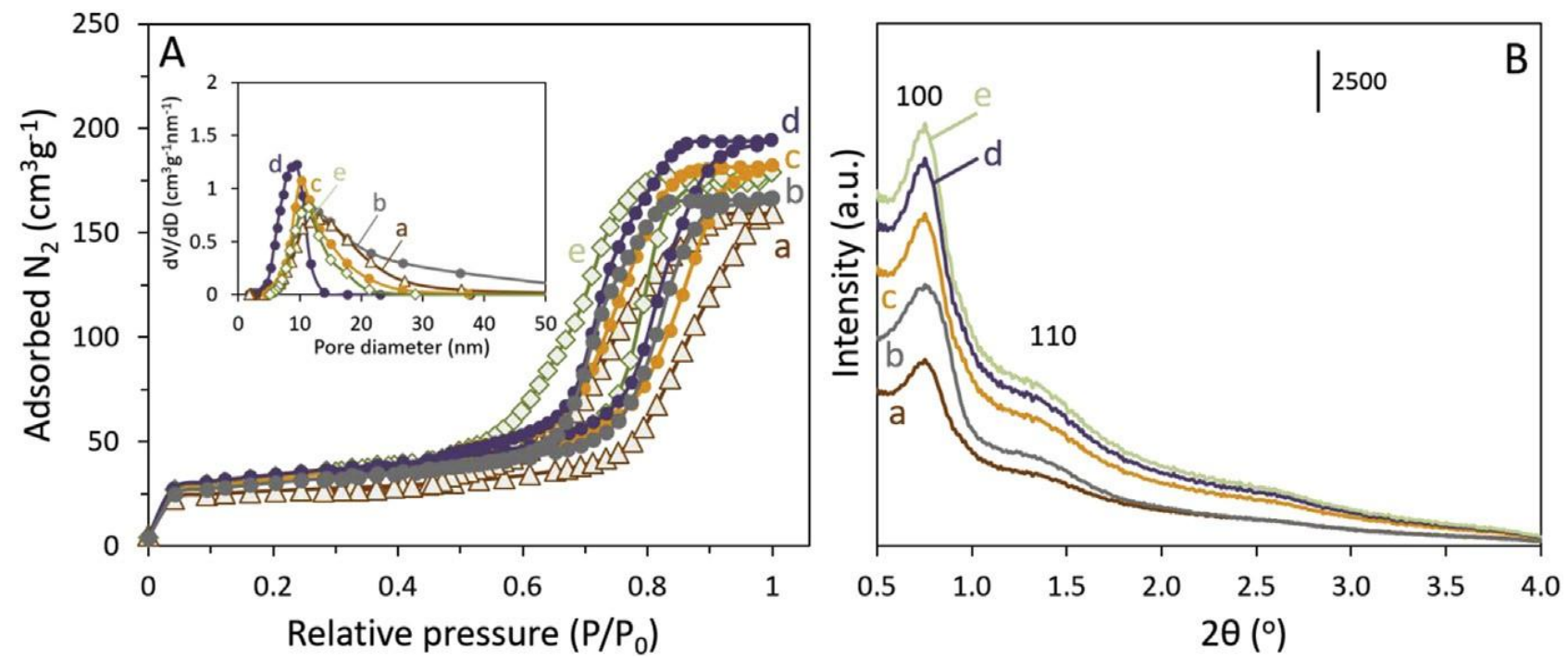

Fig. 1: (A) $\mathrm{N}_{2}$ adsorption-desorption isotherms along with pore size distributions (insets) and (B) small angle XRD patterns of in-situ reduced (700 ${ }^{\circ} \mathrm{C} / 2 \mathrm{~h}, \mathrm{H}_{2} / \mathrm{Ar}$ ) materials: (a) $\mathrm{Fe}_{10 \%} \mathrm{Al}_{2} \mathrm{O}_{3}$, (b) $\mathrm{Fe}_{7.5 \%} \mathrm{Ni}_{2.5 \%} \mathrm{Al}_{2} \mathrm{O}_{3}$, (c) $\mathrm{Fe}_{5 \%} \mathrm{Ni}_{5 \%} \mathrm{Al}_{2} \mathrm{O}_{3}$, (d) $\mathrm{Fe}_{2.5 \%} \mathrm{Ni}_{7.5 \%} \mathrm{Al}_{2} \mathrm{O}_{3}$ and (e) $\mathrm{Ni}_{5 \%} \mathrm{Al}_{2} \mathrm{O}_{3}$. For XRD patterns, an offset was applied along the $Y$-axis for the sake of clarity. 

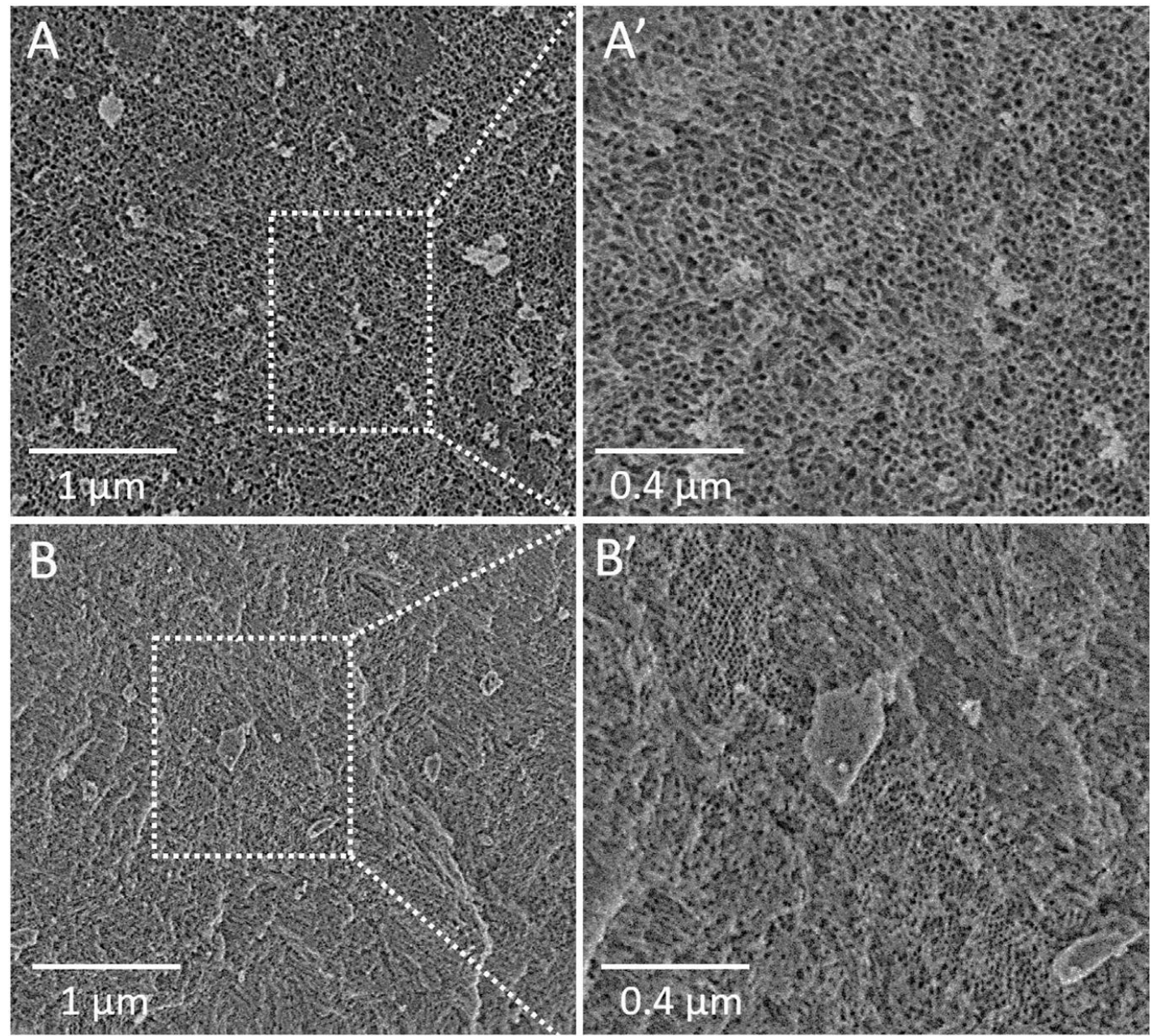

Fig. 2: SEM micrographs of in-situ reduced (700 $\left.\mathrm{O} / 2 \mathrm{~h}, \mathrm{H}_{2} / \mathrm{Ar}\right)\left(\mathrm{A}-\mathrm{A}^{\prime}\right)$ $\mathrm{Fe}_{10 \%} \mathrm{Al}_{2} \mathrm{O}_{3}$ and $\left(\mathrm{B}-\mathrm{B}^{\prime}\right) \mathrm{Fe}_{5 \%} \mathrm{Ni}_{5 \%} \mathrm{Al}_{2} \mathrm{O}_{3}$ materials. 

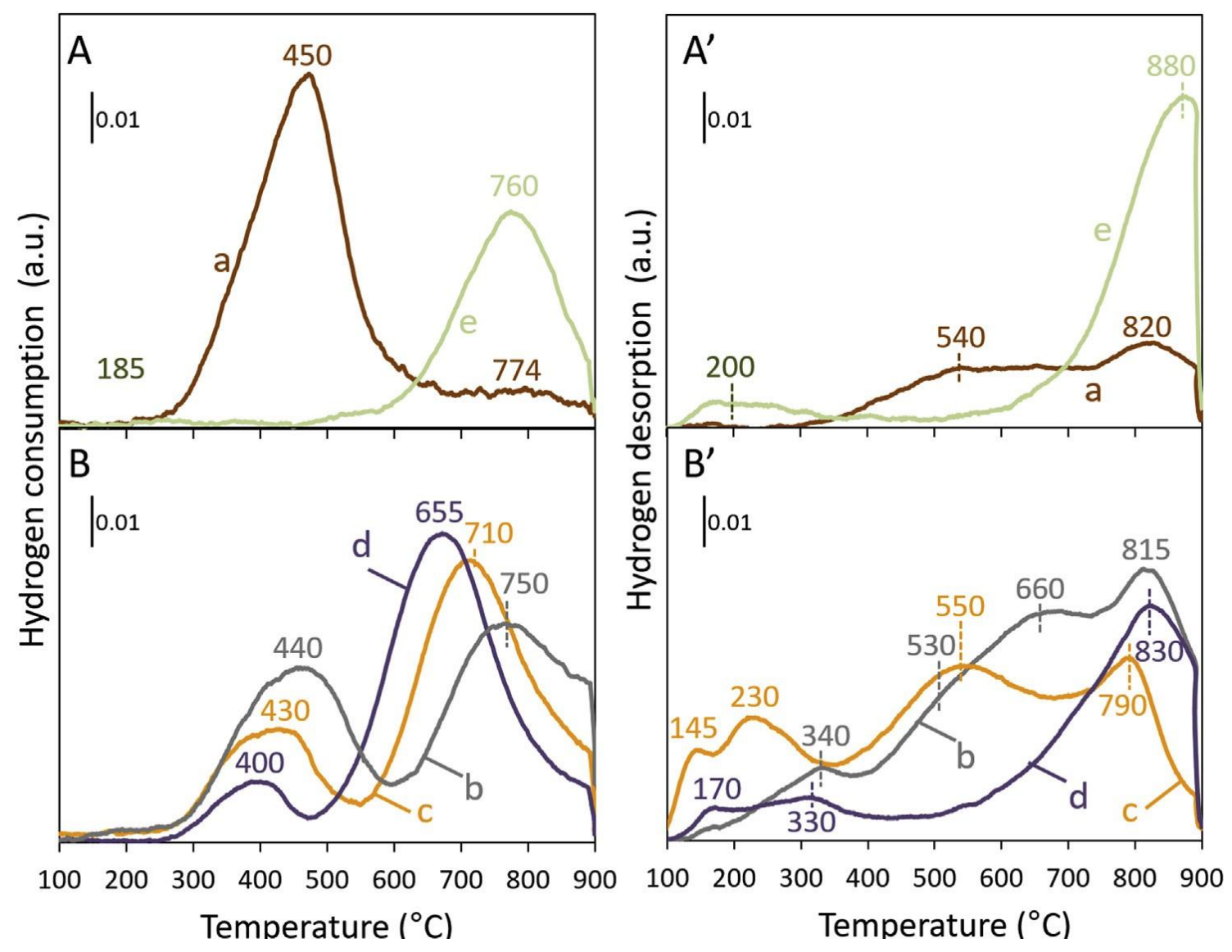

Fig. 3: (A,B) $\mathrm{H}_{2}$-TPR and $\left(A^{\prime}, B^{\prime}\right) \mathrm{H}_{2}$-TPD profiles of alumina basedmaterials: (a) $\mathrm{Fe}_{10 \%} \mathrm{Al}_{2} \mathrm{O}_{3}$, (b) $\mathrm{Fe}_{7.5 \%} \mathrm{Ni}_{2.5 \%} \mathrm{Al}_{2} \mathrm{O}_{3}$, (c) $\mathrm{Fe}_{5 \%} \mathrm{Ni}_{5 \%} \mathrm{Al}_{2} \mathrm{O}_{3}$, (d) $\mathrm{Fe}_{2.5 \%} \mathrm{Ni}_{7.5 \%} \mathrm{Al}_{2} \mathrm{O}_{3}$ and $(\mathrm{e}) \mathrm{Ni}_{5 \%} \mathrm{Al}_{2} \mathrm{O}_{3}$. 


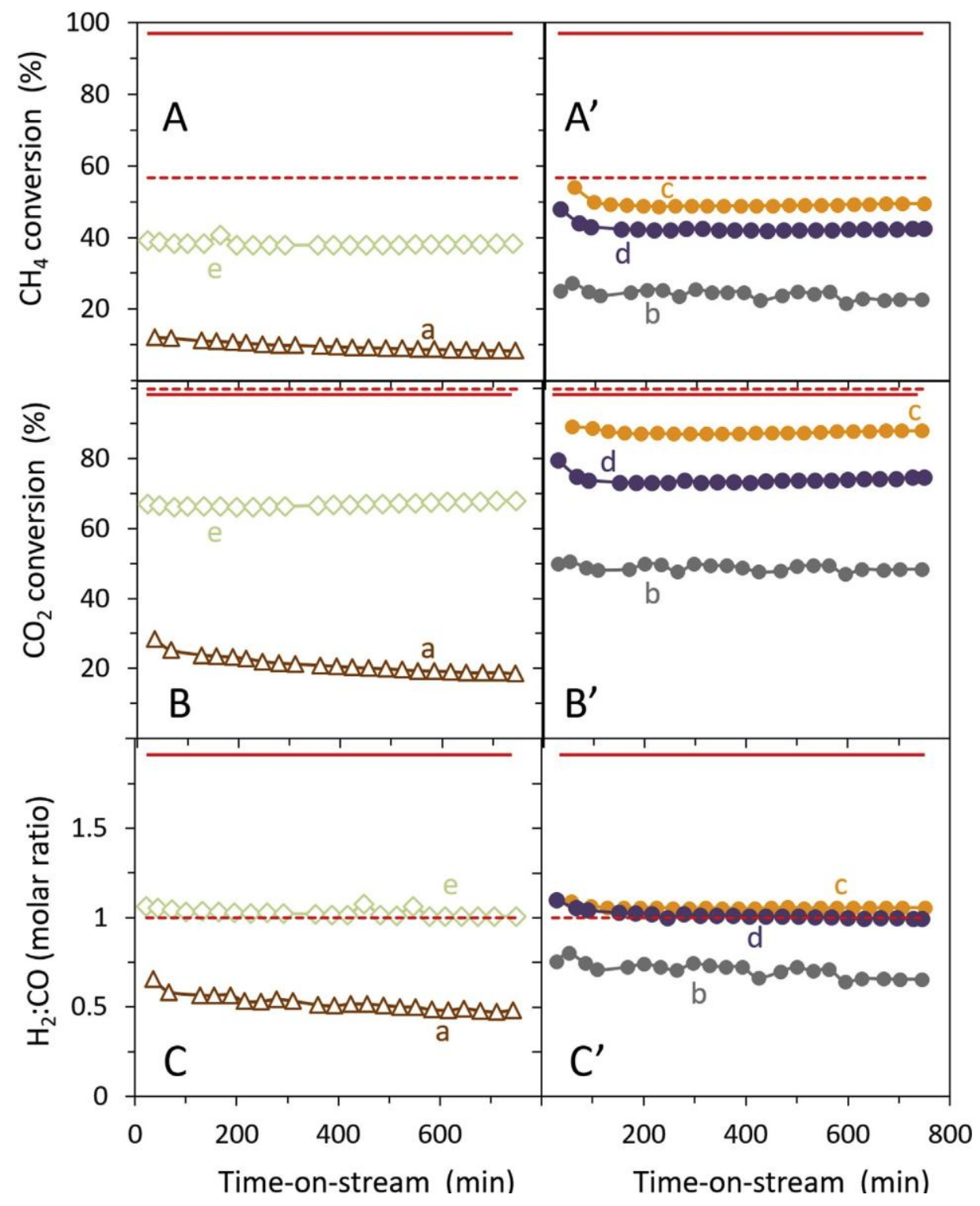

Fig. 4: $\left(A, A^{\prime}\right) \mathrm{CH}_{4}$ conversions, $\left(B, B^{\prime}\right) \mathrm{CO}_{2}$ conversions and $\left(C, C^{\prime}\right) \mathrm{H}_{2}: \mathrm{CO}$ molar product ratios during biogats dry reforming $(700 \circ \mathrm{C} / 13 \mathrm{~h}$, $\mathrm{CH}_{4} / \mathrm{CO}_{2} / \mathrm{Ar} 1 / 41.8 / 1 / 14, \mathrm{P} 1 / 41 \mathrm{~atm}, \mathrm{GHSV} 1 / 436 \mathrm{Lg}^{\mathrm{i} 1} \mathrm{hr}^{\mathbf{i} 1}$ ) as a function of time-on-stream over: (a) $\mathrm{Fe}_{10 \%} \mathrm{Al}_{2} \mathrm{O}_{3}$, (b) $\mathrm{Fe}_{7.5 \%} \mathrm{Ni}_{2.5 \%} \mathrm{Al}_{2} \mathrm{O}_{3}$, (c) $\mathrm{Fe}_{5 \%} \mathrm{Ni}_{5 \%} \mathrm{Al}_{2} \mathrm{O}_{3}$, (d) $\mathrm{Fe}_{2.5 \%} \mathrm{Ni}_{7.5 \%} \mathrm{Al}_{2} \mathrm{O}_{3}$ and (e) $\mathrm{Ni}_{5 \%} \mathrm{Al}_{2} \mathrm{O}_{3}$. Straight-lines and dashed-lines are thermodynamic values calculated respectively, with the HSC 7.1 Chemistry software, for $\mathrm{C}_{\mathrm{s}}$-assisted and $\mathrm{C}_{\mathrm{s}}$-free operations. 


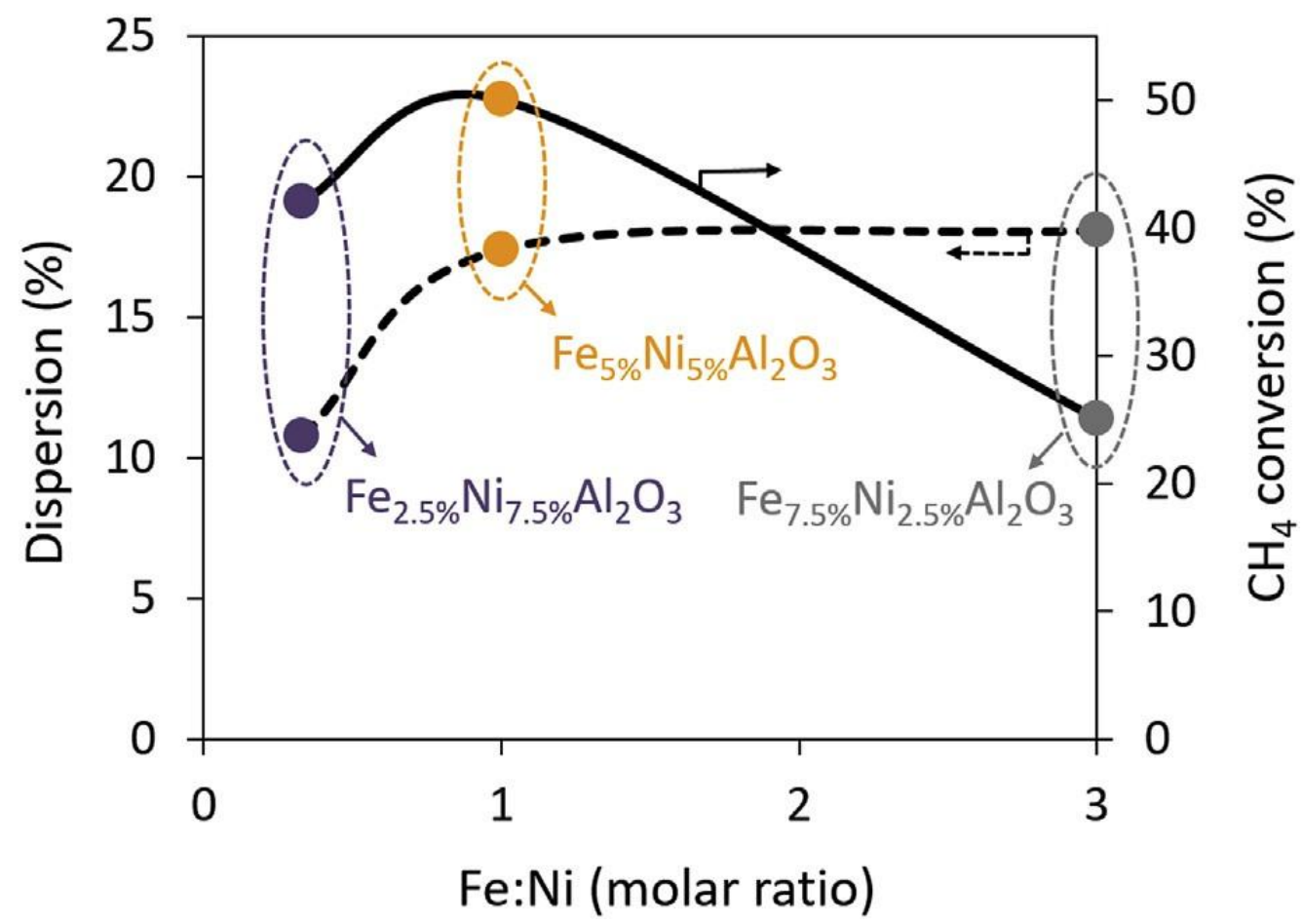

Fig. 5: Correlation between metal dispersion and reactivity levels (mean methane conversion) as a function of the molar Ni:Fe ratio introduced during preparation of bimetallic $\mathrm{Fe}-\mathrm{Ni}$ mesoporous samples. 


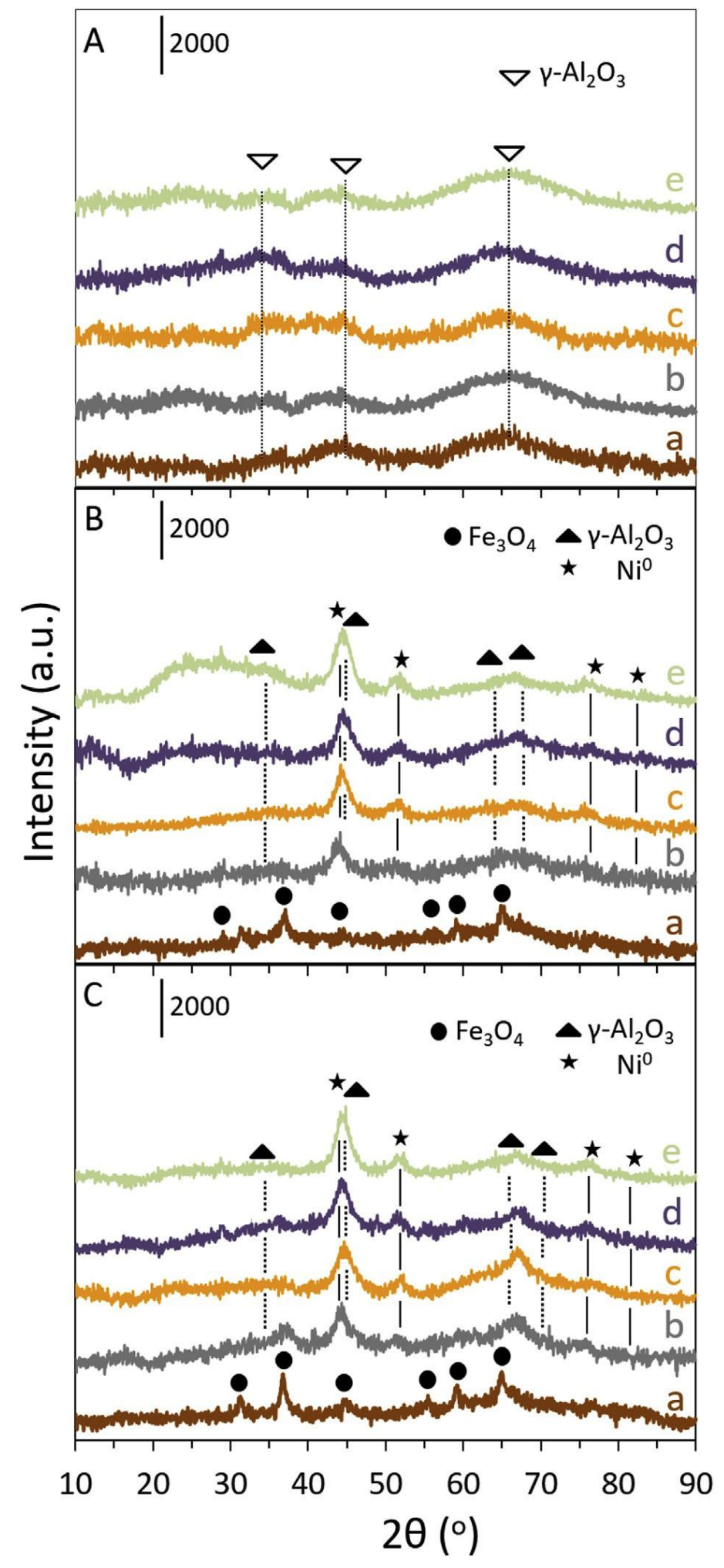

Fig. 6: XRD patterns of (A) calcined (B) in-situ reduced $(700 \circ \mathrm{C} / 2 \mathrm{~h}$, $\mathrm{H}_{2} / \mathrm{Ar}$ ) and (C) spent (700 $\mathrm{O} / 13 \mathrm{~h}, \mathrm{CH}_{4} / \mathrm{CO}_{2} / \mathrm{Ar} 1 / 4$ 1.8/1/14, $\mathrm{P} 1 / 41 \mathrm{~atm}$,

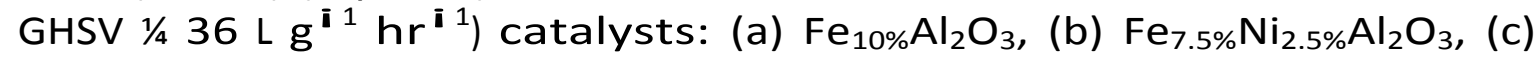
$\mathrm{Fe}_{5 \%} \mathrm{Ni}_{5 \%} \mathrm{Al}_{2} \mathrm{O}_{3}$, (d) $\mathrm{Fe}_{2.5 \%} \mathrm{Ni}_{7.5 \%} \mathrm{Al}_{2} \mathrm{O}_{3}$ and (e) $\mathrm{Ni}_{5 \%} \mathrm{Al}_{2} \mathrm{O}_{3}$. 

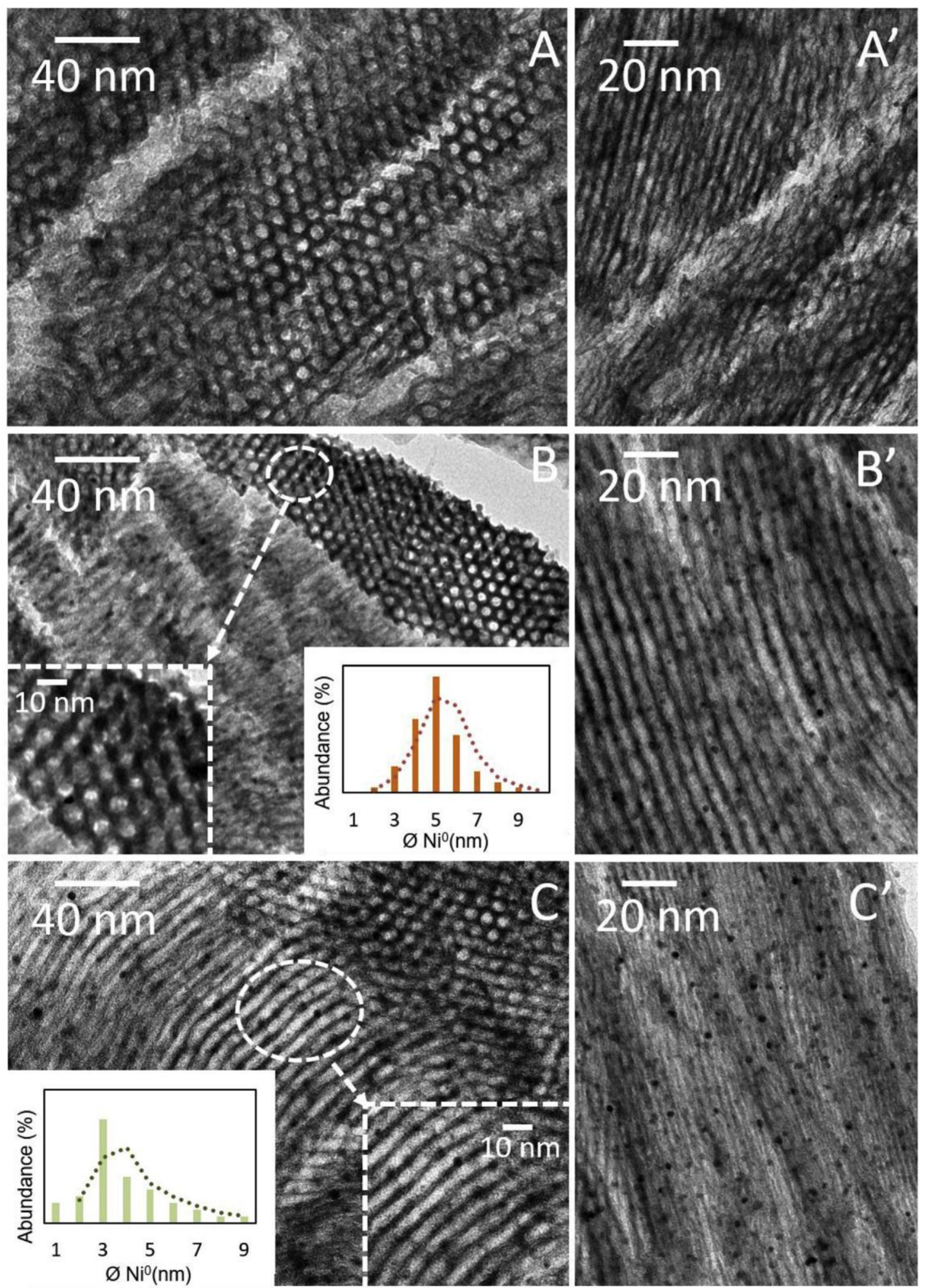

Fig. 7: TEM micrographs of spent $\left(700^{\circ} \mathrm{C} / 13 \mathrm{~h}, \mathrm{CH}_{4} / \mathrm{CO}_{2} / \mathrm{Ar} 1 / 41.8 / 1 / 14, \mathrm{P} 1 / 4\right.$ 1 atm, GHSV $1 / 436 \mathrm{Lg}^{\mathbf{i}} \mathrm{hr}^{\mathbf{i}}{ }^{1}$ ) (A-A') $\mathrm{Fe}_{10 \%} \mathrm{Al}_{2} \mathrm{O}_{3}$, (B-B') $\mathrm{Fe}_{5 \%} \mathrm{Ni}_{5 \%} \mathrm{Al}_{2} \mathrm{O}_{3}$ and (C$\left.C^{\prime}\right) \mathrm{Ni}_{5 \%} \mathrm{Al}_{2} \mathrm{O}_{3}$ catalysts. Insets in Figs. $\mathrm{B}$ and $\mathrm{C}$ show zooms on the specified grain zones. 


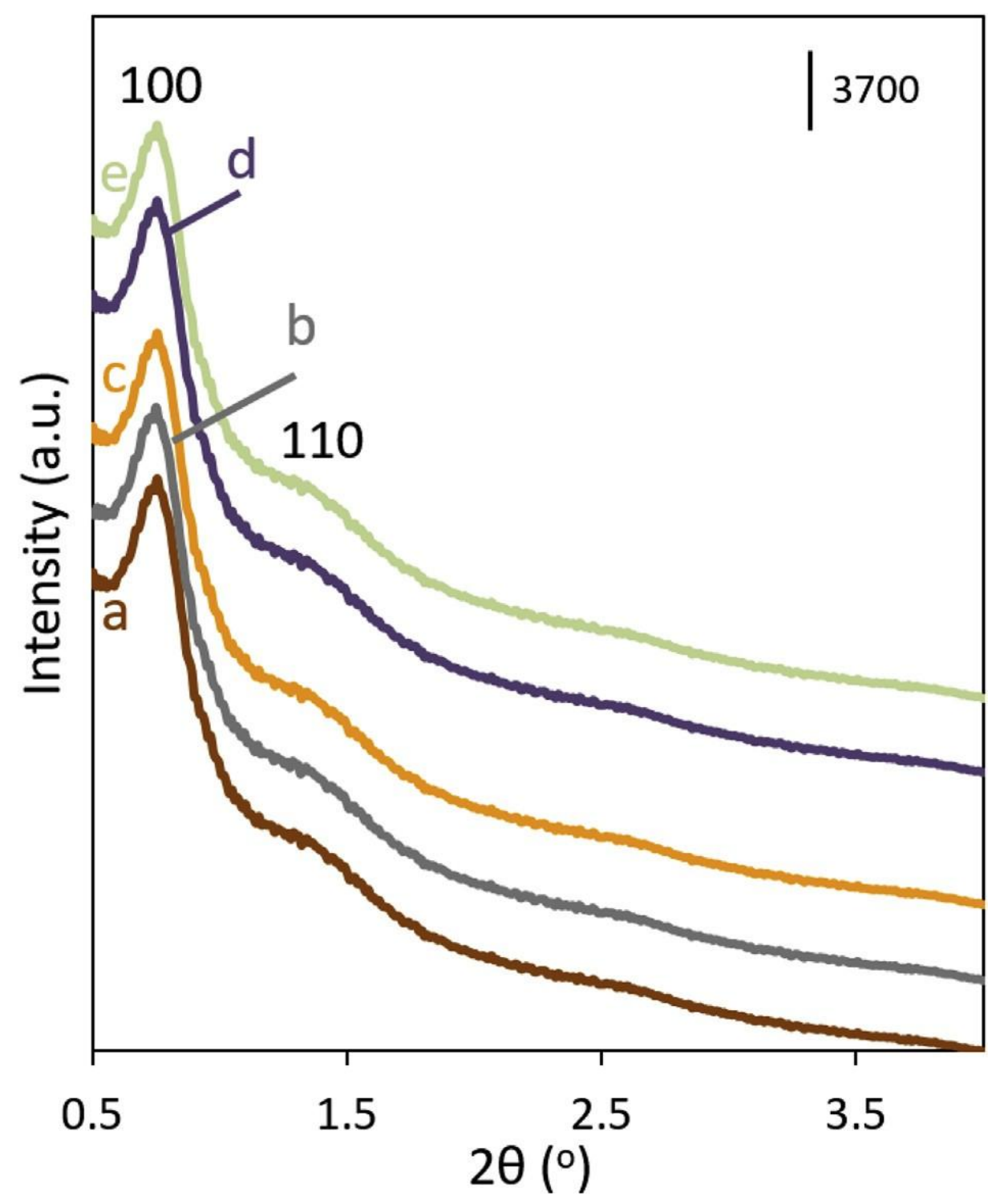

Fig. 8: Small angle XRD patterns of spent $\left(700{ }^{\circ} \mathrm{C} / 13 \mathrm{~h}, \mathrm{CH}_{4} / \mathrm{CO}_{2} / \mathrm{Ar} 1 / 4\right.$ 1.8/1/14, P 1/4 1 atm, GHSV 1/4a $36 \mathrm{Lg}^{\mathbf{1}} \mathrm{hr}^{\mathbf{i}}$ ) catalysts: (a) $\mathrm{Fe}_{10 \%} \mathrm{Al}_{2} \mathrm{O}_{3}$, (b) $\mathrm{Fe}_{7.5 \%} \mathrm{Ni}_{2.5 \%} \mathrm{Al}_{2} \mathrm{O}_{3}$, (c) $\mathrm{Fe}_{5 \%} \mathrm{Ni}_{5 \%} \mathrm{Al}_{2} \mathrm{O}_{3}$, (d) $\mathrm{Fe}_{2.5 \%} \mathrm{Ni}_{7.5 \%} \mathrm{Al}_{2} \mathrm{O}_{3}$ and (e) $\mathrm{Ni}_{5 \%} \mathrm{Al}_{2} \mathrm{O}_{3}$. An offset was applied along the $Y$-axis for the sake of clarity. 

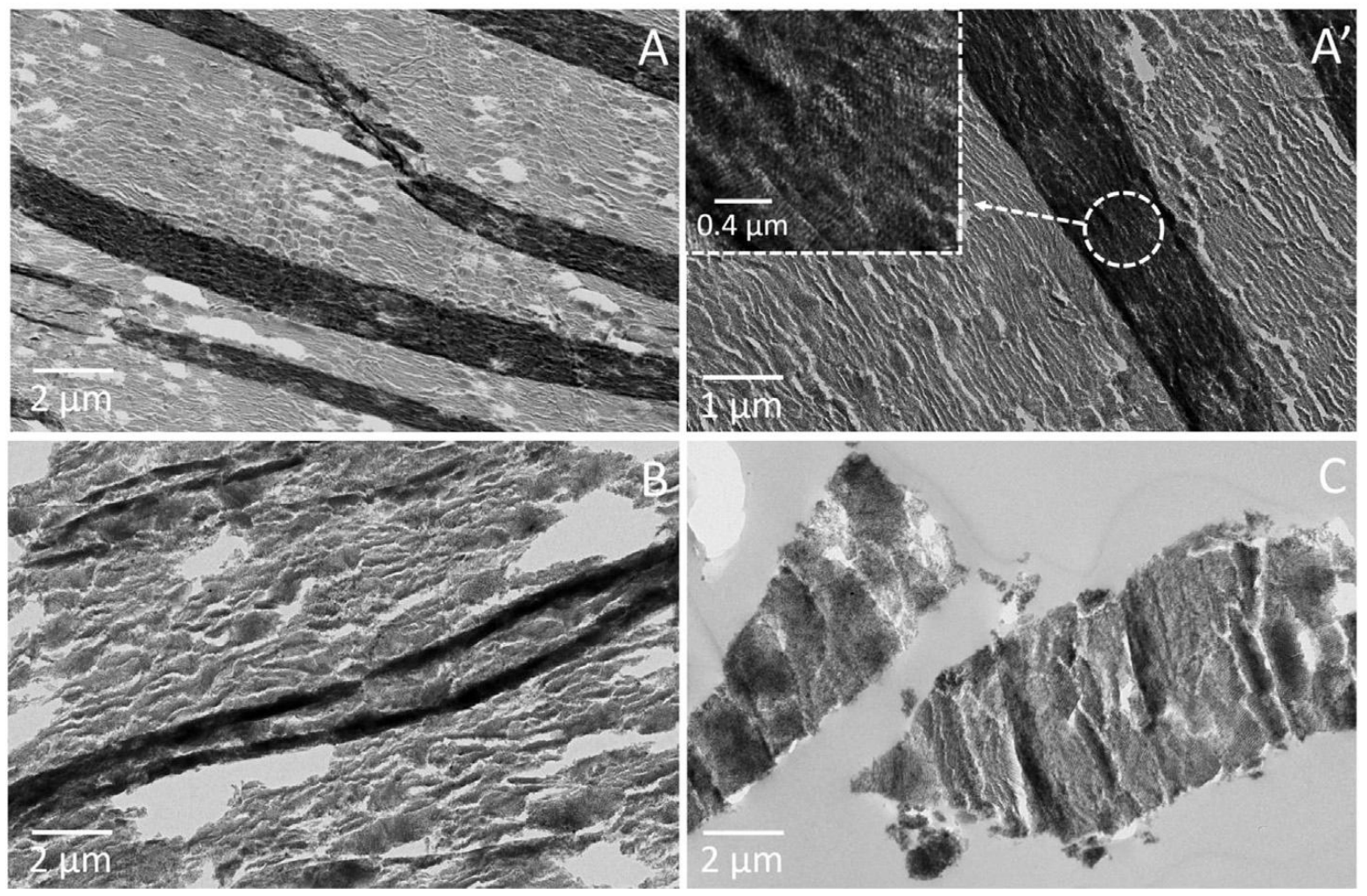

Fig. 9: TEM micrographs of spent $\left(700^{\circ} \mathrm{C} / 13 \mathrm{~h}, \mathrm{CH}_{4} / \mathrm{CO}_{2} / \mathrm{Ar} 1 / 41.8 / 1 / 14, \mathrm{P} 1 / 4\right.$ 1 atm, GHSV $1 / 436 \mathrm{Lg}^{\mathbf{i} 1} \mathrm{hr}^{\mathbf{i}}{ }^{1}$ ) (A-A') $\mathrm{Fe}_{10 \%} \mathrm{Al}_{2} \mathrm{O}_{3}$, (B) $\mathrm{Fe}_{5 \%} \mathrm{Ni}_{5 \%} \mathrm{Al}_{2} \mathrm{O}_{3}$ and (C) $\mathrm{Ni}_{5 \%} \mathrm{Al}_{2} \mathrm{O}_{3}$ catalysts. Inset in Fig. $A^{\prime}$ shows zoom on the specified grain zone. 


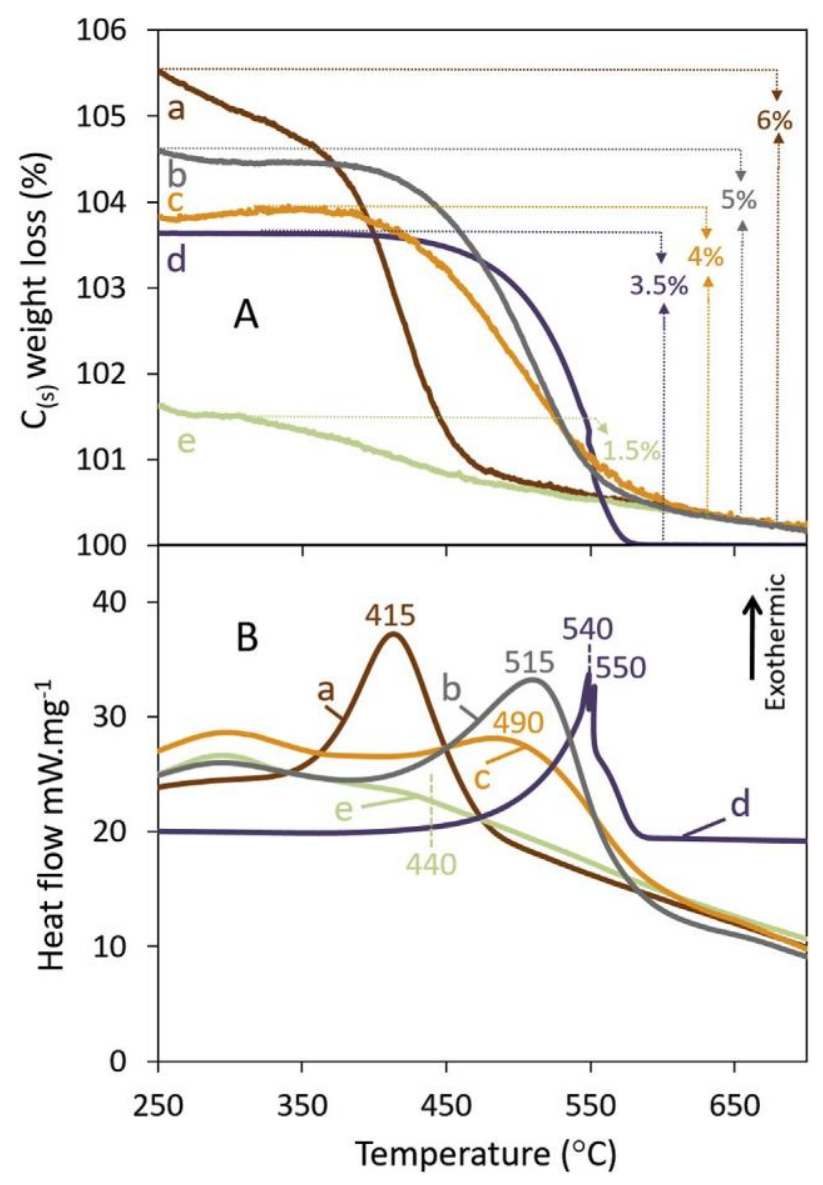

Fig. 10: (A) TGA and (B) DSC profiles of spent (700 $\mathrm{OC} / 13 \mathrm{~h}, \mathrm{CH}_{4} / \mathrm{CO}_{2} / \mathrm{Ar} 1 / 4$ 1.8/1/14, $\mathrm{P} 1 / 41 \mathrm{~atm}$, GHSV $1 / 436 \mathrm{Lg}^{\mathbf{1}} \mathrm{hr}^{\mathrm{i}}{ }^{1}$ ) catalysts: (a) $\mathrm{Fe}_{10 \%} \mathrm{Al}_{2} \mathrm{O}_{3}$, (b) $\mathrm{Fe}_{7.5 \%} \mathrm{Ni}_{2.5 \%} \mathrm{Al}_{2} \mathrm{O}_{3}$, (c) $\mathrm{Fe}_{5 \%} \mathrm{Ni}_{5 \%} \mathrm{Al}_{2} \mathrm{O}_{3}$, (d) $\mathrm{Fe}_{2.5 \%} \mathrm{Ni}_{7.5 \%} \mathrm{Al}_{2} \mathrm{O}_{3}$ and (e) $\mathrm{Ni}_{5 \%} \mathrm{Al}_{2} \mathrm{O}_{3} \mathrm{Fig}$. $10 \mathrm{e}$ (A) TGA and (B) DSC profiles of spent (700 $\mathrm{O} \mathrm{C} / 13 \mathrm{~h}, \mathrm{CH}_{4} / \mathrm{CO}_{2} / \mathrm{Ar} 1 / 4$ 1.8/1/14, $\mathrm{P} 1 / 41 \mathrm{~atm}$, GHSV $1 / 436 \mathrm{Lg}^{\mathbf{1}} \mathrm{hr}^{\mathbf{1}}{ }^{1}$ ) catalysts: (a) $\mathrm{Fe}_{10 \%} \mathrm{Al}_{2} \mathrm{O}_{3}$, (b) $\mathrm{Fe}_{7.5 \%} \mathrm{Ni}_{2.5 \%} \mathrm{Al}_{2} \mathrm{O}_{3}$, (c) $\mathrm{Fe}_{5 \%} \mathrm{Ni}_{5 \%} \mathrm{Al}_{2} \mathrm{O}_{3}$, (d) 


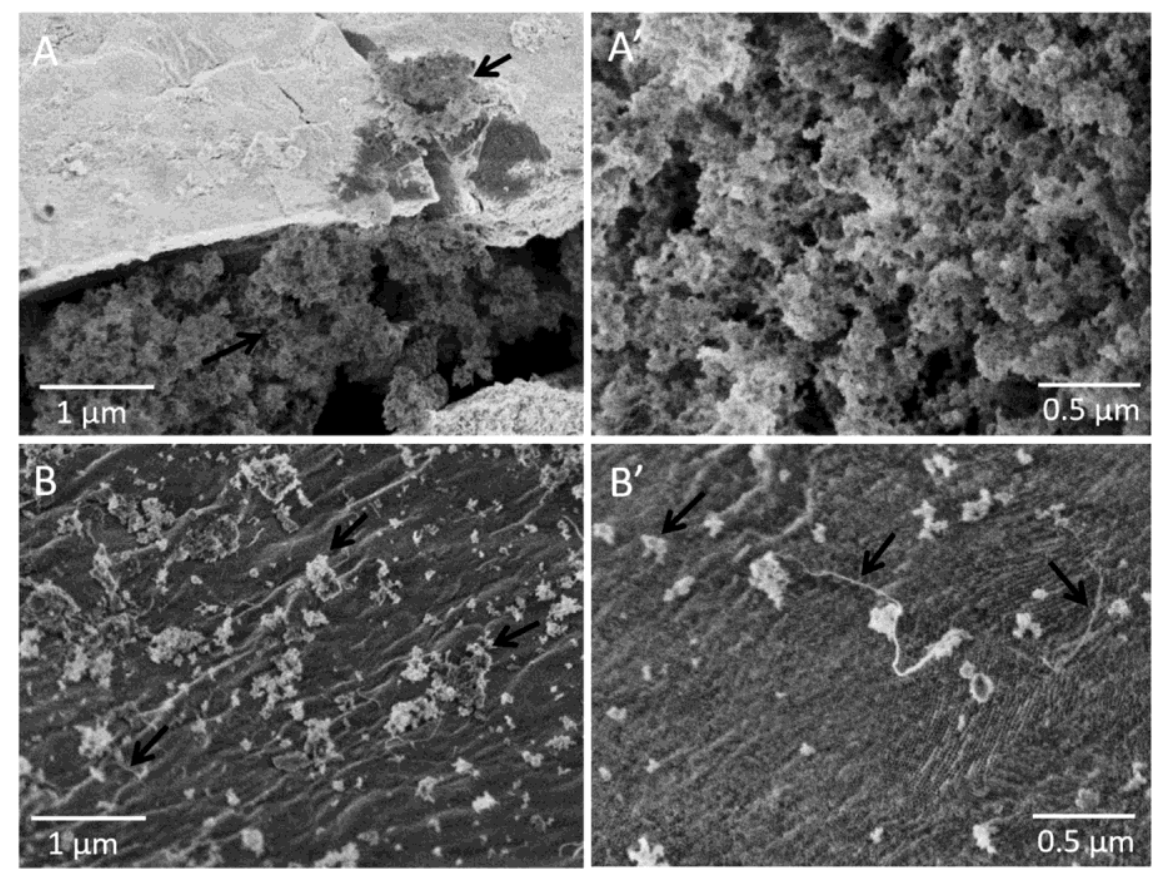

Fig. 11: SEM micrographs of spent $\left(700^{\circ} \mathrm{C} / 13 \mathrm{~h}, \mathrm{CH}_{4} / \mathrm{CO}_{2} / \mathrm{Ar} 1 / 41.8 / 1 / 14, \mathrm{P} 1 / 4\right.$ 1 atm, GHSV $1 / 436 \mathrm{Lg}^{\mathbf{i}} \mathrm{hr}^{\mathbf{i}}$ ) $\left(\mathrm{A}-\mathrm{A}^{\prime}\right) \mathrm{Fe}_{10 \%} \mathrm{Al}_{2} \mathrm{O}_{3}$ and (B-B') $\mathrm{Fe}_{5 \%} \mathrm{Ni}_{5 \%} \mathrm{Al}_{2} \mathrm{O}_{3}$ catalysts. Some carbon deposits are marked with arrows. 


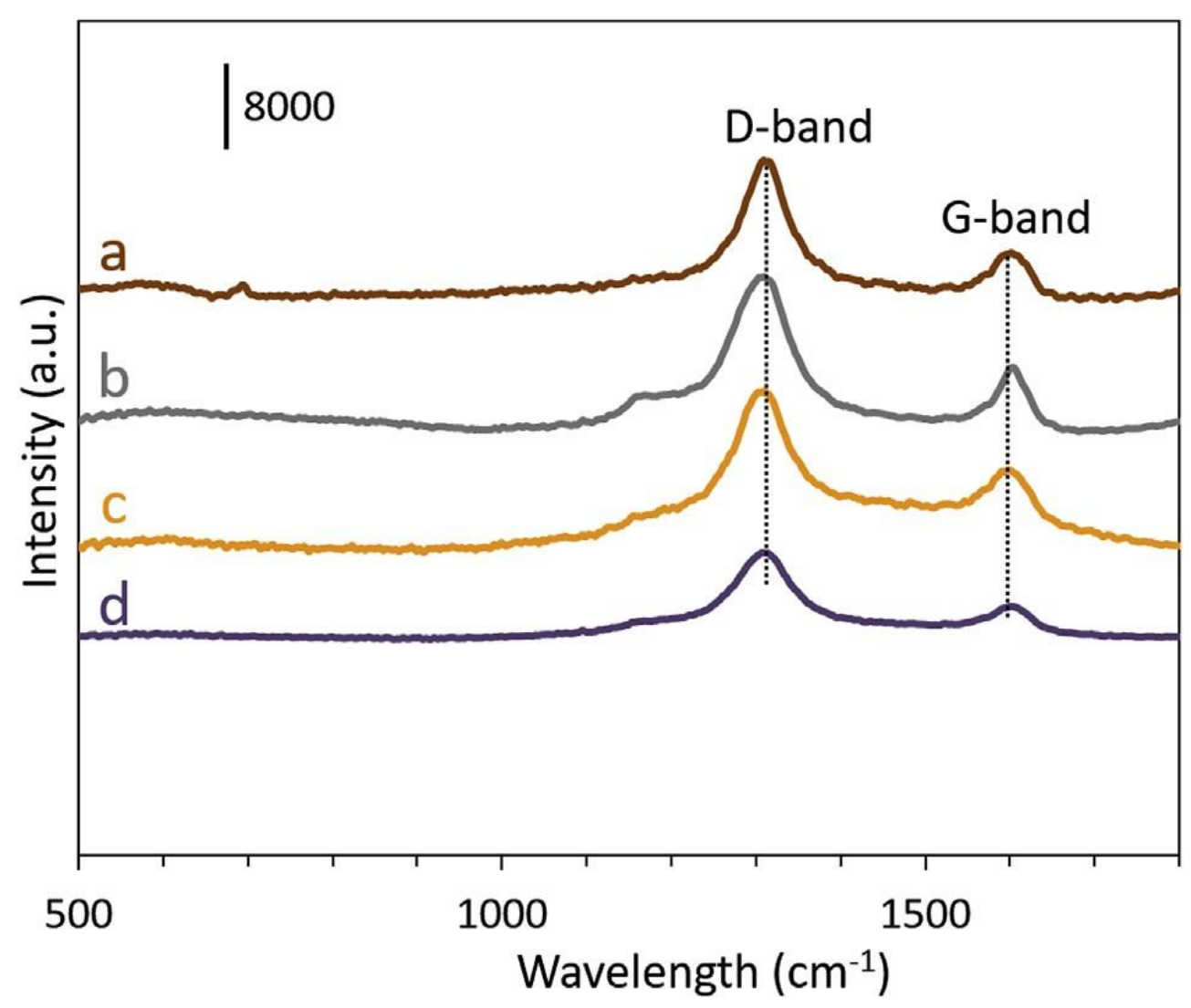

Fig. 12: Raman spectra and of spent (700 $0 \mathrm{C} / 13 \mathrm{~h}, \mathrm{CH}_{4} / \mathrm{CO}_{2} / \mathrm{Ar} 1 / 4$ 1.8/1/14, P $1 / 41$ atm, GHSV $1 / 436 \mathrm{~L} \mathrm{~g}^{\mathbf{i}} \mathrm{hr}^{\mathbf{i}}{ }^{1}$ ) catalysts: (a) $\mathrm{Fe}_{10 \%} \mathrm{Al}_{2} \mathrm{O}_{3}$, (b) $\mathrm{Fe}_{7.5 \%} \mathrm{Ni}_{2.5 \%} \mathrm{Al}_{2} \mathrm{O}_{3}$, (c) $\mathrm{Fe}_{5 \%} \mathrm{Ni}_{5 \%} \mathrm{Al}_{2} \mathrm{O}_{3}$, (d) $\mathrm{Fe}_{2.5 \%} \mathrm{Ni}_{7.5 \%} \mathrm{Al}_{2} \mathrm{O}_{3}$ and (e) $\mathrm{Ni}_{5 \%} \mathrm{Al}_{2} \mathrm{O}_{3}$. An offset was applied along the $Y$-axis for the sake of clarity. 